\title{
الاستفادة هن بعض الشعب المرجانية للبحر الأحمر في إثراء التصميم الزخرفي لفساتين السهرة
}

\author{
إعلداد \\ د/ أملرس عبد السميع \\ مدرس الملابس والنسيج بقسم الاقتصاد المنزلي \\ كلية التربية النوعية - جامعة المنصورة
}

مجلة بحوث التربية النوعية ـ جامعة المنصورة

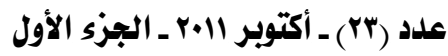




\title{
الاستفادة هن بعض الشعب المرجانية لاببر الأحمر \\ في إثراء التصميم الزخرفي لفساتين السهرة
}

\author{
إعداد \\ دأمل عبد السميع
}

\section{:}

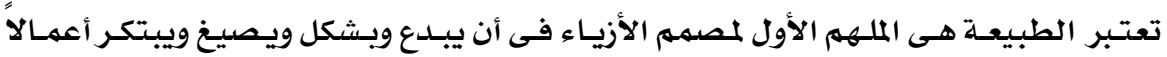

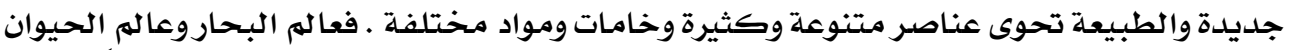

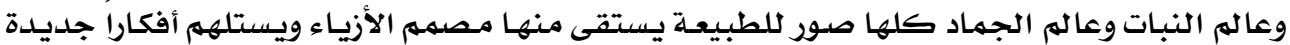

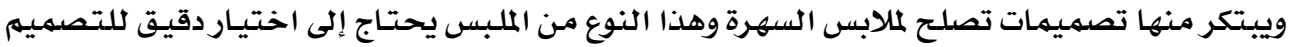

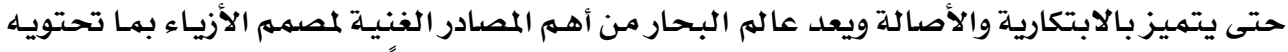

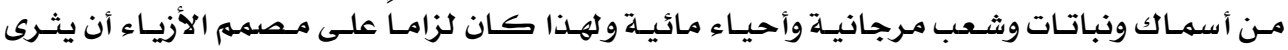

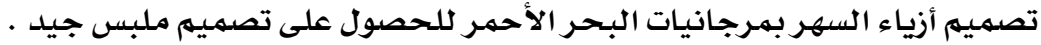

* مدرس الملابس والنسيج بقسه الاقتصاد المنزلي - كلية التربية النوعية - جامعة المنصورة 


\title{
الاستفادة هن بعض الشعب المرجانية للبحر الأحمر في إثراء التصميم الزخرفي لفساتين السهرة
}

\author{
إعداد \\ * أمل عبد السميع
}

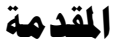

تعد صناعة الملابس الجاهزة من أهم الصناعات التى يرتكز عليها الاقتصاد القومى حيث زاد

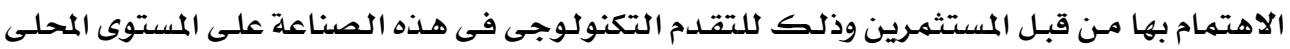

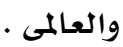

وفى الآونة الأخيرة اهتم مصمهى الأزياء بالارتقاء بتصميمات الملابس للوصول إلى العالميـة

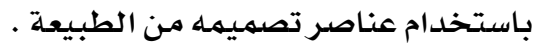
فيجب على مصمهم الأزيـاء الزيـاء أن يعمـل على إثراء العمليـة الابتكاريـة إلى جانب دراستـه

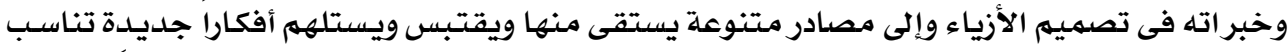

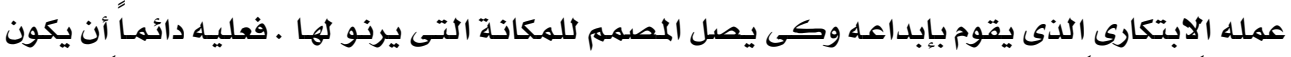

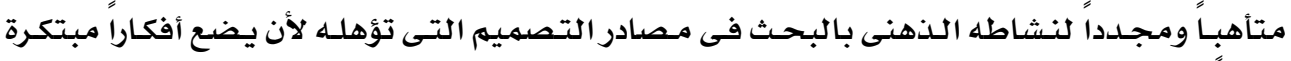

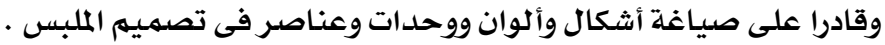

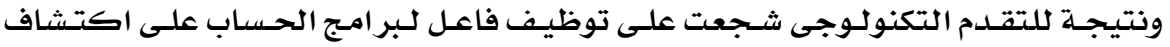

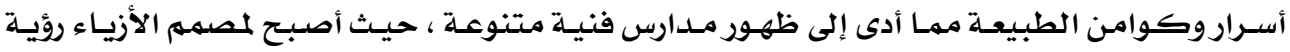

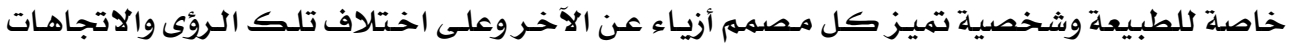

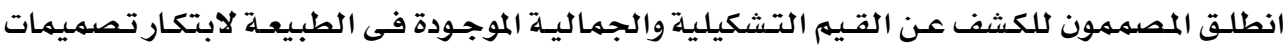

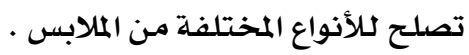

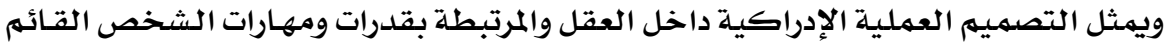

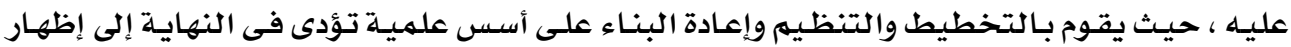

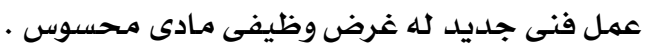

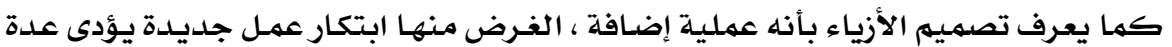

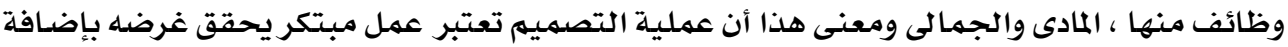

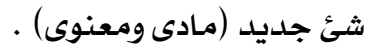

* مدرس الملابس والنسيج بقسم الاقتصاد المنزلي - كلية التربية النوعية - جامعة المنصورة 


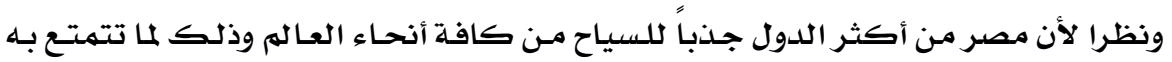

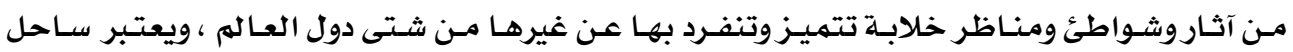

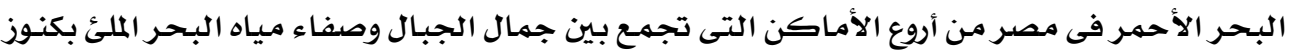

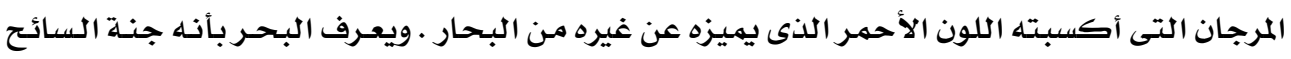

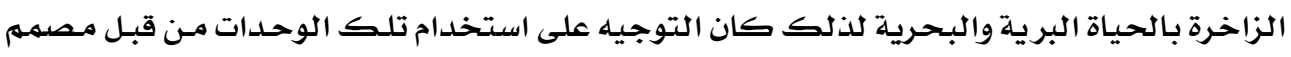

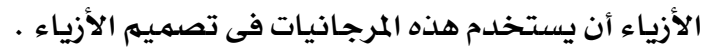

\section{مشكلة البمث : مشاء ان}

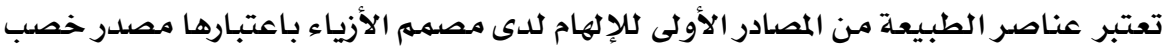

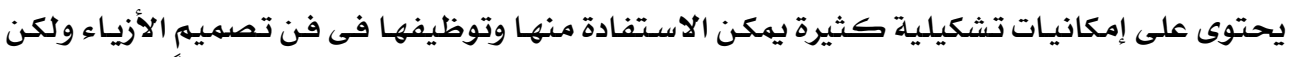

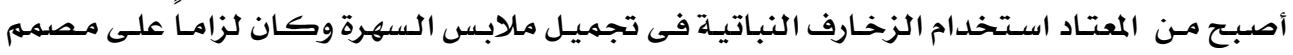

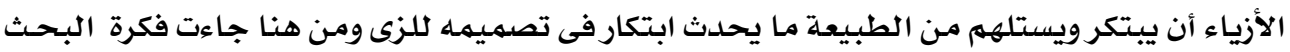

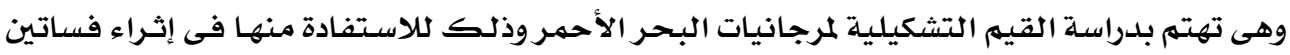

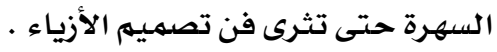

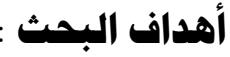

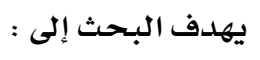

ا ـ الاستفادة من الشعب المرجانية فى تصميهم ملابس السهرة .

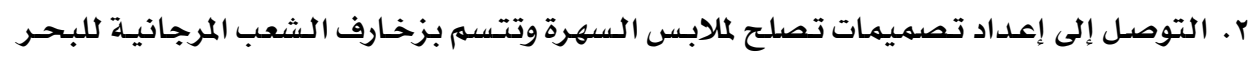

الأحمر . التوصل

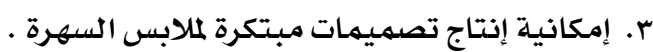

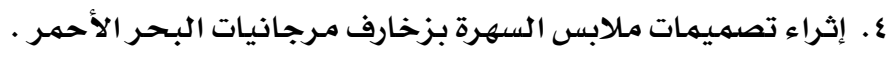

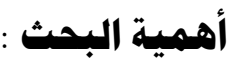

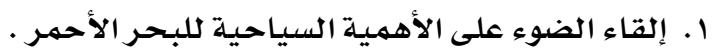

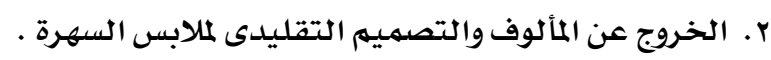

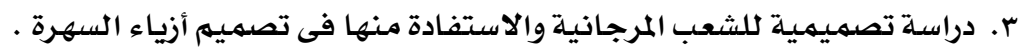

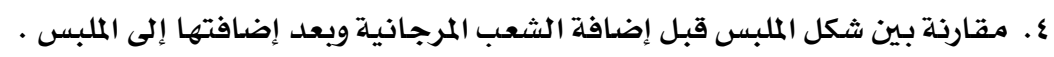

ا. توجـد علاقـة ذات دالــة إحصـائية بـين عناصـر الشعب المرجانيـة للبحـر الأحمـرو وإثراء الناحيـة

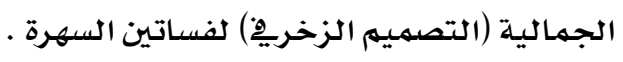

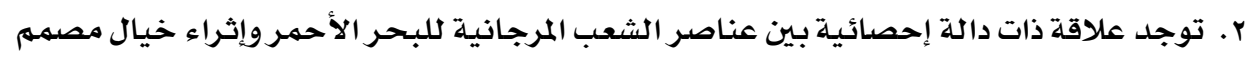

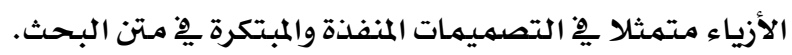




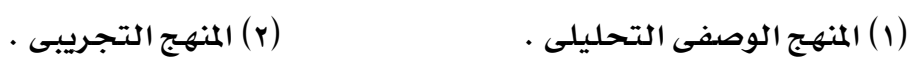

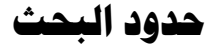

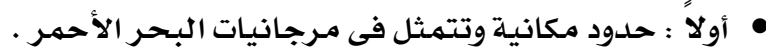

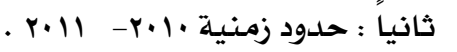

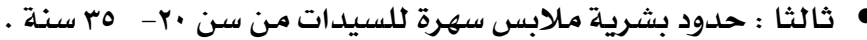

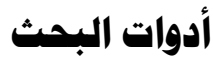

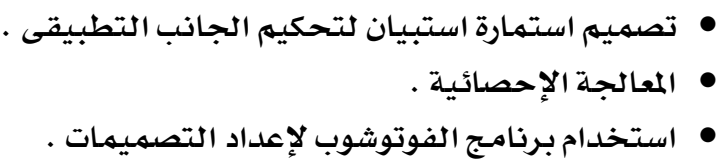

هصطات البحث

•

هى تلك العملية الابتكاريـة الكامل لتخطيط شكل ما وإنشائه بطريقة مرضية مـن الناحيـة

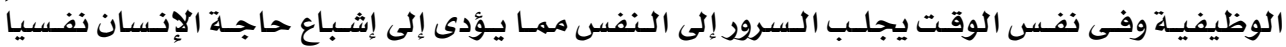

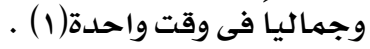

• تصميم الأزياء : تصناء

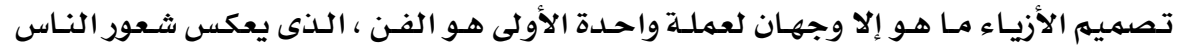

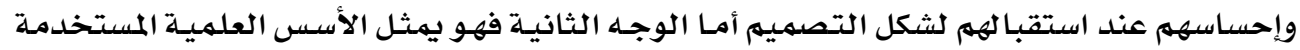

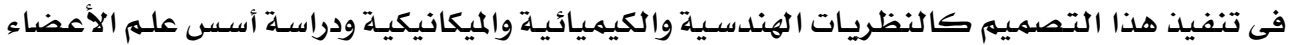

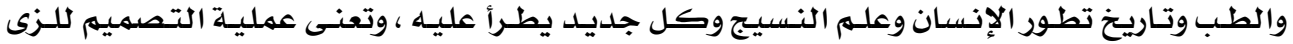

اكتشاف لطبيعة وهيئة الجسم ، ثم التعبير عن تلك الهيئة من خلال التهان التصميم المبتكر( ع ) .

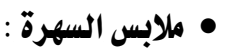

وترتدى هذه الملابس فى الحفلات المسائية وتتميز بتصميماتها المميزة والتى ترتبط بالموضسة

$$
\text { فى ذلك الوقت(ه) (وترتئ هذه }
$$

والقماث الذى يستخدم فى إنتاجها ما يكون لامعاً وبراقاً أو شفافاً وكثيراً مـا يتهم تحميلها ألتها

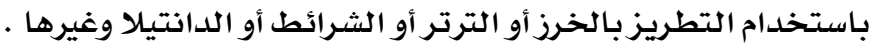
•

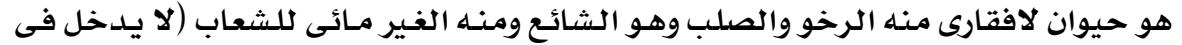

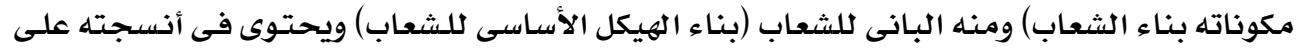

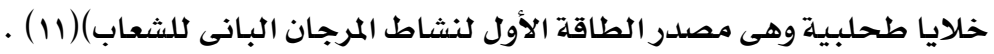




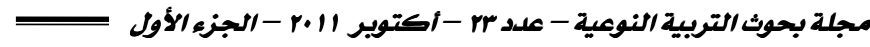

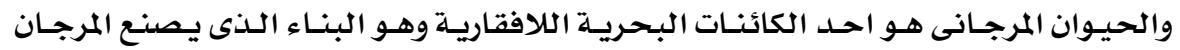

ويبنى شعابه وينشئ مستعمراته( ( ) .

وينتهى المرجان إلى شعبة الجوفمعويات والتى تمتاز أغلب حيواناتها بأنها حيوانات صغيرة

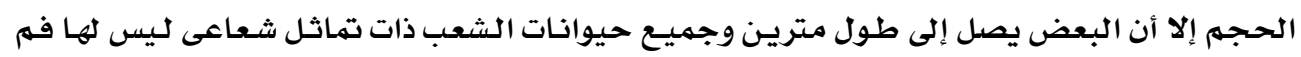

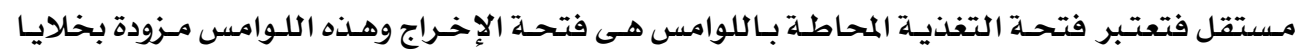

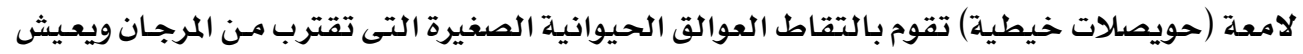

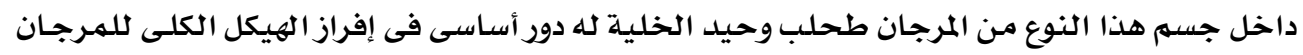

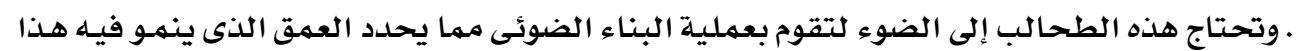

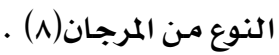

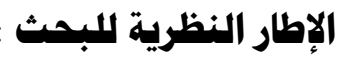

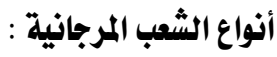

تنقسه الشعاب المرجاني إلى ثلاث أنواع أساسية :

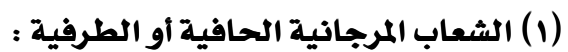

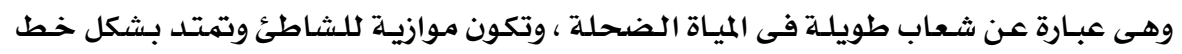

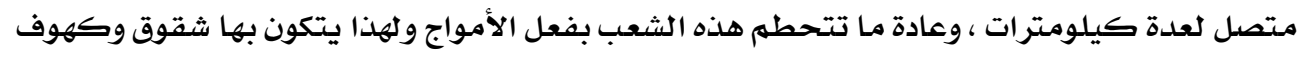

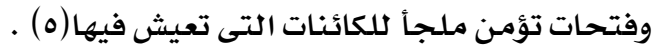

: (r) (r) الشعاب المرجانية الحاجزية

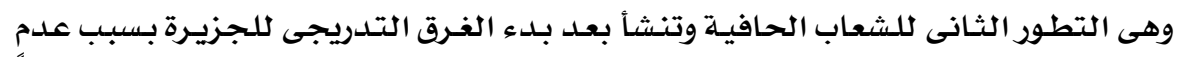

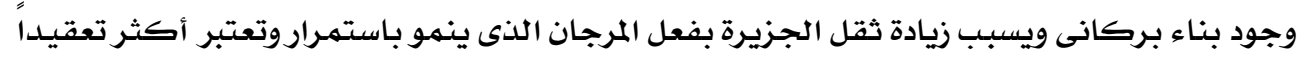

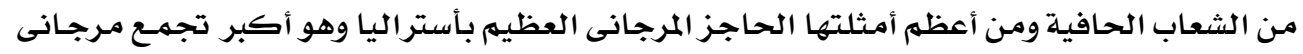
على كوكب الأرض . من الشئ
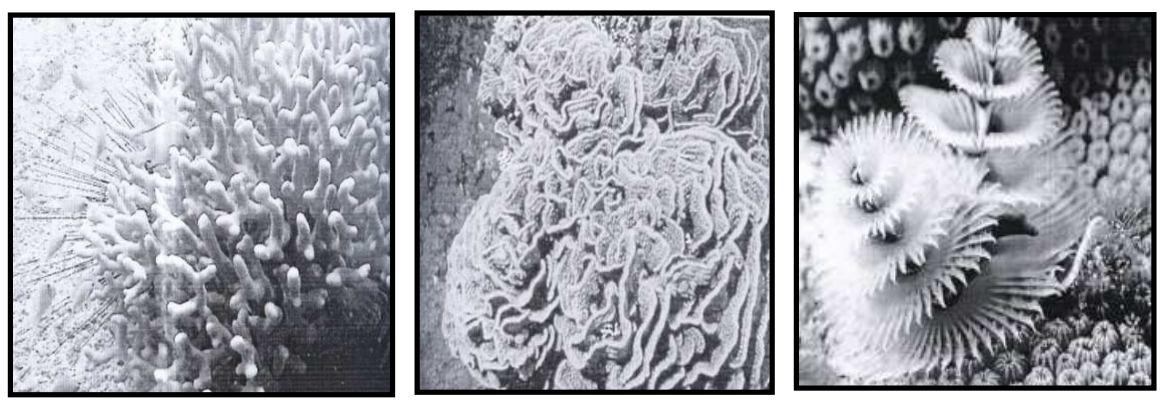


\section{سـ الاستفادة من بعض الشعب المرجانية للبحر الأحمر فِ إثراء التصميم الزخرٍِ لفساتين السهرة \\ بعض أنواع المرجان :}

المرجسان النفـيس : وهـو نوع مـن المرجـان لا يعيث على الشعاب المرجانيـة ويعيش فى الميـاه

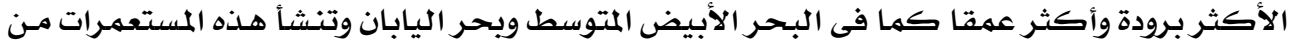

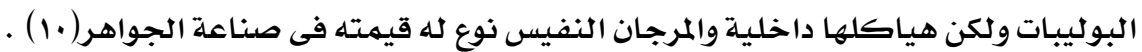

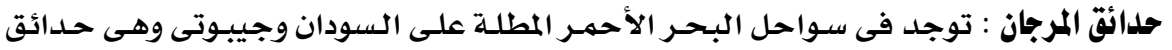

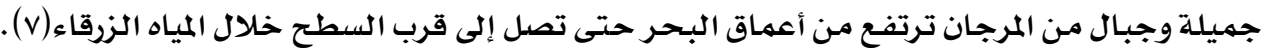
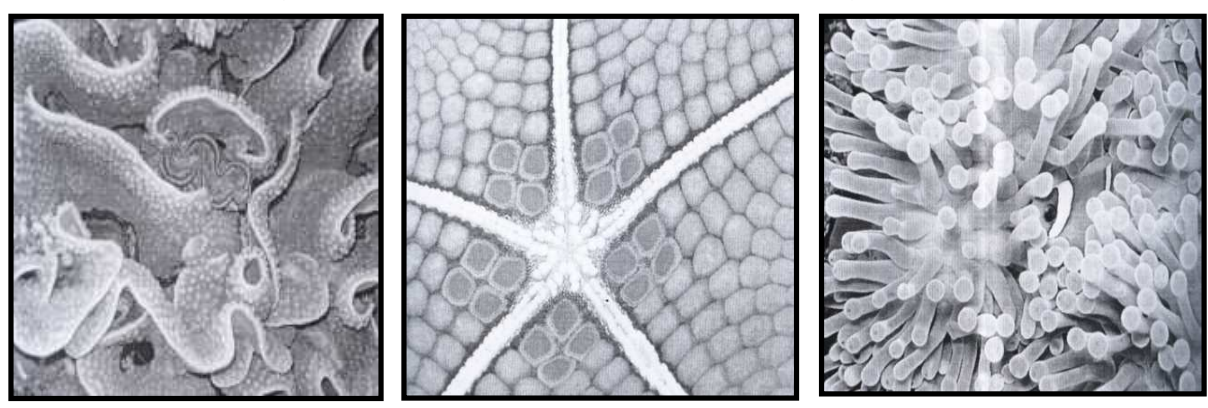

ولتصميم الأزياء نوعان هما :

(أ) التصميم البنائى The Structural Design ويتضمن الخطوط البنائيسة التى تظهر شكل الجسهم المراد ابتكار زى يناسبه فتظهر أهميته فى اختيـار وترتيـب الخطوط والأثـكال والألكوان

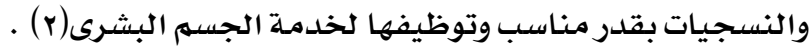

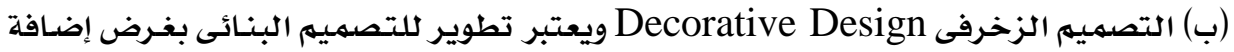

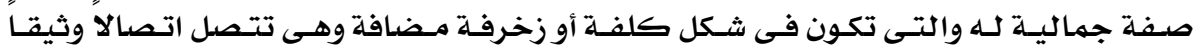

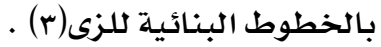

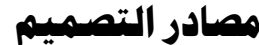

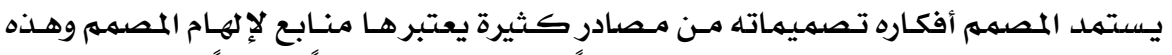

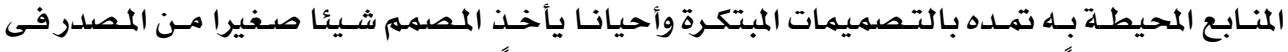

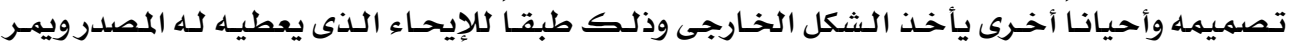

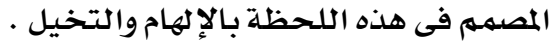
: (ا) مصادر طبيعية

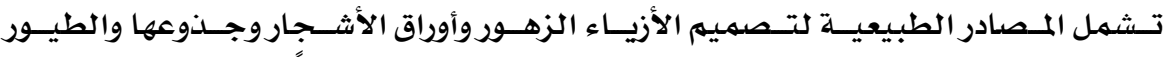

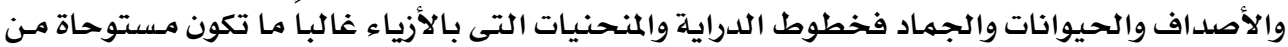
الحركات غير السـاكنة الموجودة فى الطبيعة(؟) . 


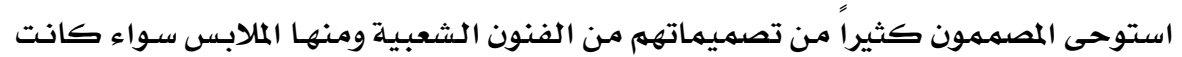

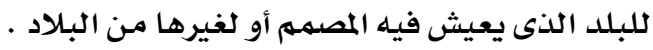

: (") مصادر تاريخية

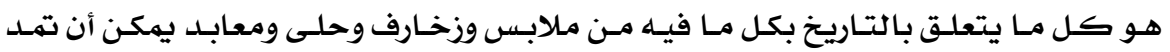

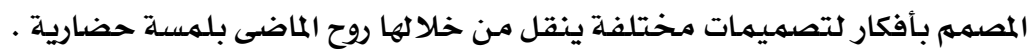

: (צ) مصادر فنية

يستوحى المصمهمون خطـوطهم مـن فن المعهمار الحسديث كناطحسات السـحاب والمبـانى ذات

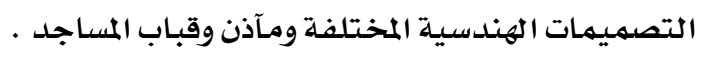

أو المجلات المتخصصدة فى الموضة فهى مصدر فنى متخصص ومشتملة على كافة المعلومات

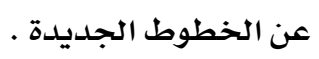

:

تشتمل كـل مـا يتعلـق بالابتكـارات الحديثـة فى الأقهـشة التطـورات الحديثـة فـى الآلات

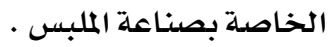

\section{إجراءات البحث :}

أولاً : تحديد التصميمات المقترحة للدراسة : تم إعداد عدد 10 تصميم لملابس السهرة روعى فيها

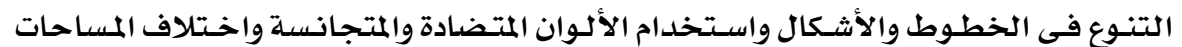

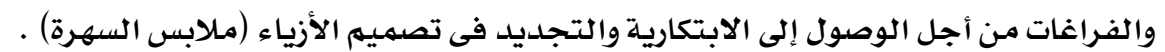

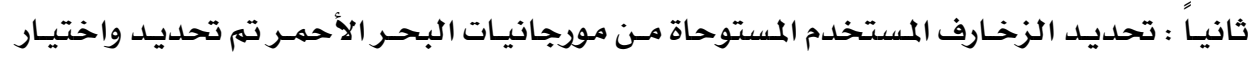

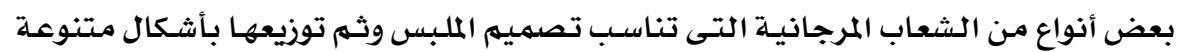

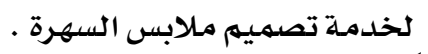

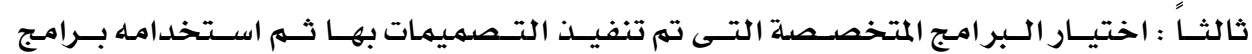

$$
\begin{aligned}
& \text { الفوتوشوب. } \\
& \text { رابعا : إعداد مقياس التقدير : الفوتوبن }
\end{aligned}
$$

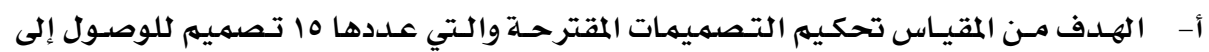

$$
\text { أفضل التصميمات وأيهم حقق هدف البح البحث . }
$$

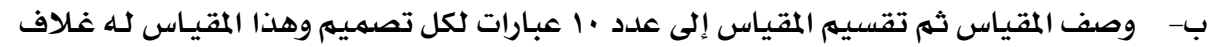

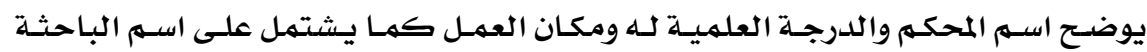

$$
\text { وعنوان البحث والهـدف من البحث والمطلوب القيام به من قبل المبل المحكمه . }
$$

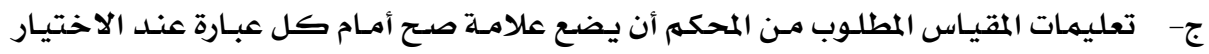


د- صدق مقياس التقدير الصلدق باستخدام الاتسـاق الداخلي بـين درجـة كل عبـارة والدرجـة

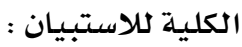

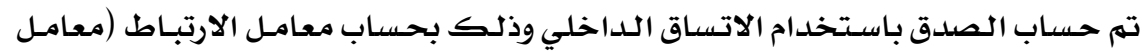

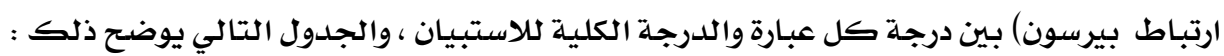
جدول (1) قيه معاملات الارتباط بين درجة كل عبارة والدرجة الكلية للاستبيان

\begin{tabular}{|c|c|c|c|c|c|}
\hline الدلالة & الارتباط & م & الدلالة & الارتبـاط & $\hat{~}$ \\
\hline$\cdot, \cdot 1$ & $\cdot, \wedge \varepsilon 1$ & 7 & $\cdot, \cdot 1$ & $\cdot, 1 \cdot 9$ & 1 \\
\hline$\cdot, \cdot 1$ & , VYA & $\mathrm{V}$ & $\cdot, \cdot 1$ & $\cdot, \Lambda \wedge V$ & $r$ \\
\hline$\cdot, \cdot 1$ & $\cdot, q \cdot v$ & $\Lambda$ & $\cdot, \cdot 1$ & $\cdot, V \cdot \varepsilon$ & $r$ \\
\hline$\cdot, \cdot 1$ & $\cdot, V 71$ & 9 & $\cdot, \cdot 1$ & $\cdot, \wedge 70$ & $\varepsilon$ \\
\hline$\cdot, \cdot 1$ & • & 1. & $\cdot, \cdot 1$ & מצq, . & 0 \\
\hline
\end{tabular}

يتضح من الجدول أن معاملات الارتباط كلها دالة عند مستوى (1., •) لاقترابها من الواحد

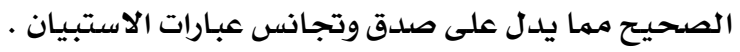
الثبات :

$$
\text { تم حساب الثبات عن طريق : }
$$

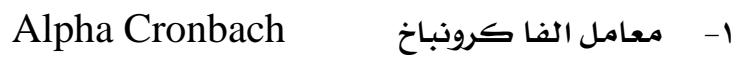
Split-half بريقة التجزئة النصفية إنساخ جدول (r) قيم معامل الثبات للاستبيان

\begin{tabular}{|c|c|c|}
\hline التجزئُة النصفية & معامل الفا & \\
\hline$\cdot, 91 r-\cdot, \wedge \varepsilon r$ & $\cdot, 9 \cdot 0$ & ثبات الاستبيـان \\
\hline
\end{tabular}

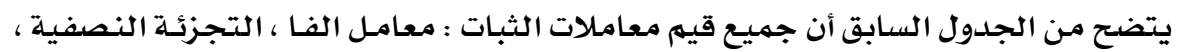
دالة عند مستوى ا.,. مما يدل على ثبات الاستبيان .

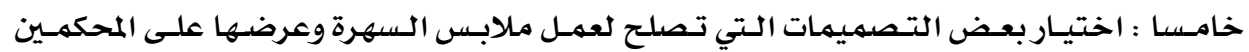

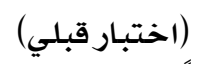

سادساً : اختيار بعض اخدياريلي المرجانيات ذات الصيغة الجمالية التى تناسب مناسب السهرة .

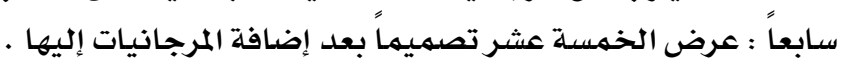


مجلة بحوث التريية النوعية - عدد rr - أكتوير |l.r - الجزء الأول بـ

التصميم الأول

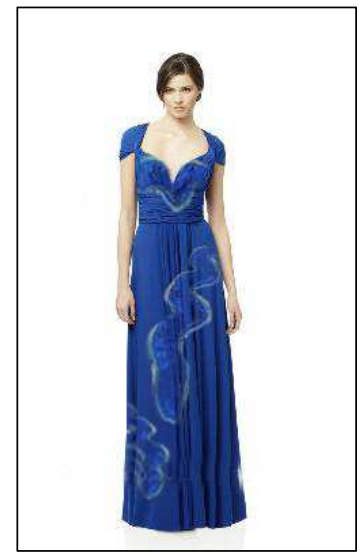

بعد إضافة التصميم

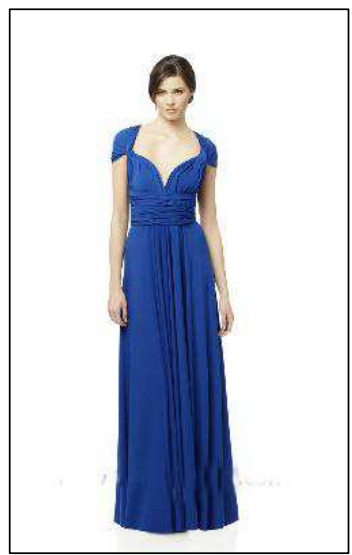

قبل إضافة التصميم

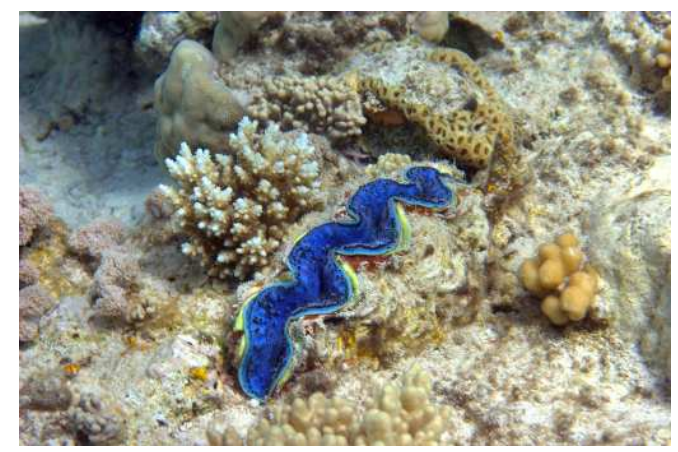

$$
\text { الوحدة المستخدمة }
$$

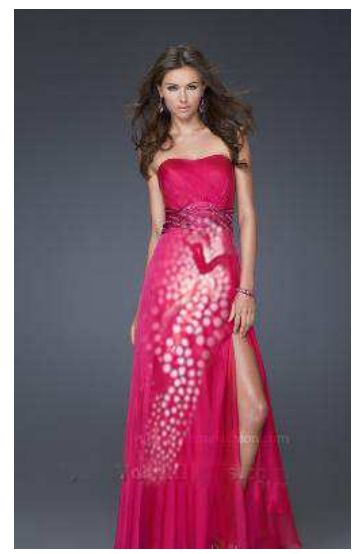

بعد إضافة التصميم

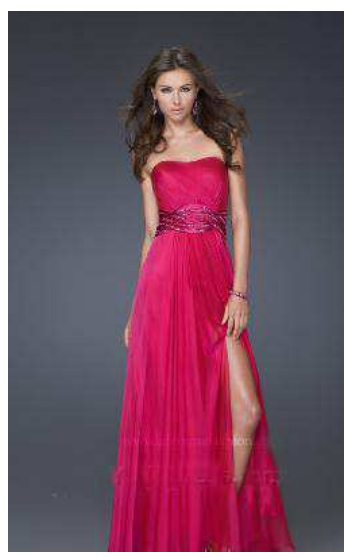

قبل إضافة التصميم 


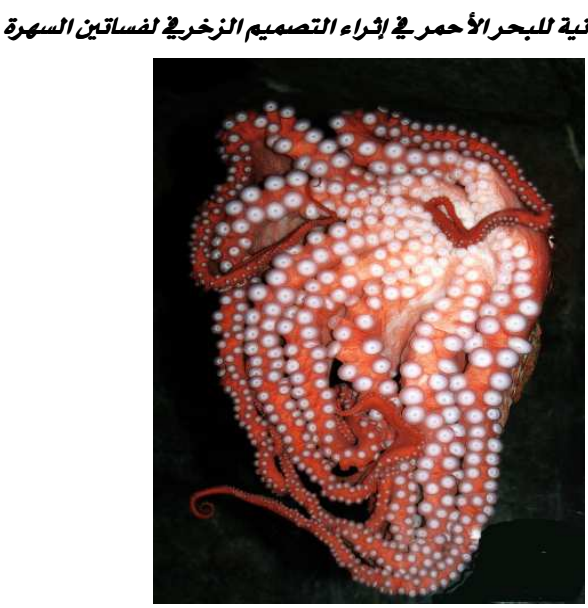

الوحدة المستخدمة

التصميي الثالث

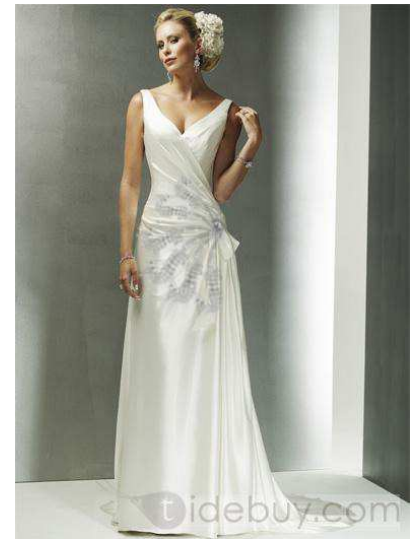

بعد إضافة التصميم

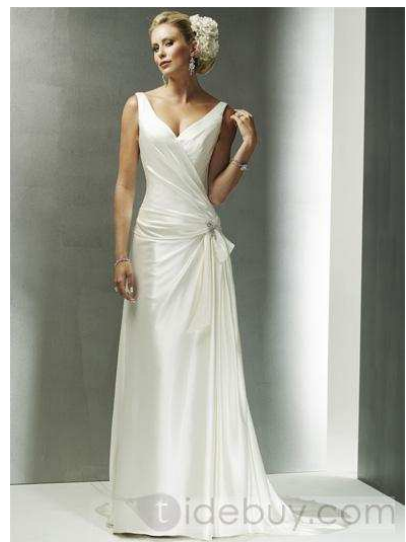

قبل إضافة التصميهم

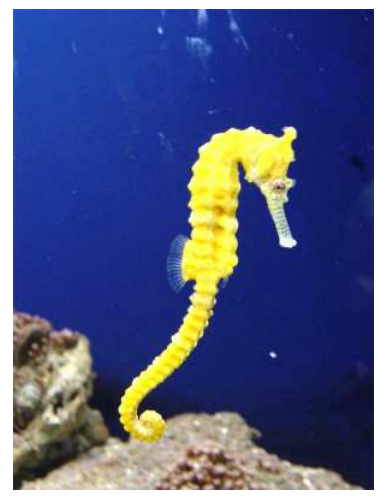

الوحدة المستخلدمـة 


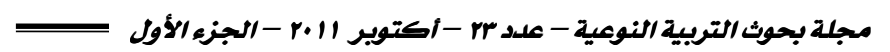

\section{التصميه الرابع}

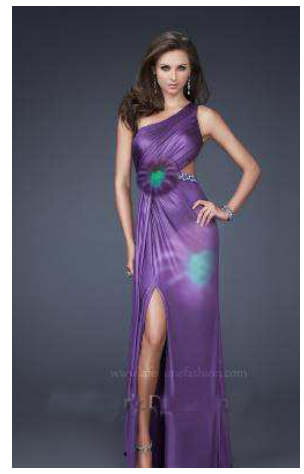

بعد إضافة التصميم

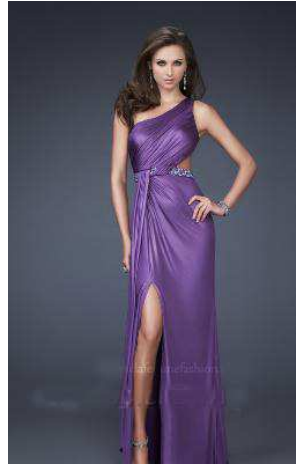

قبل إضافة التصهيم

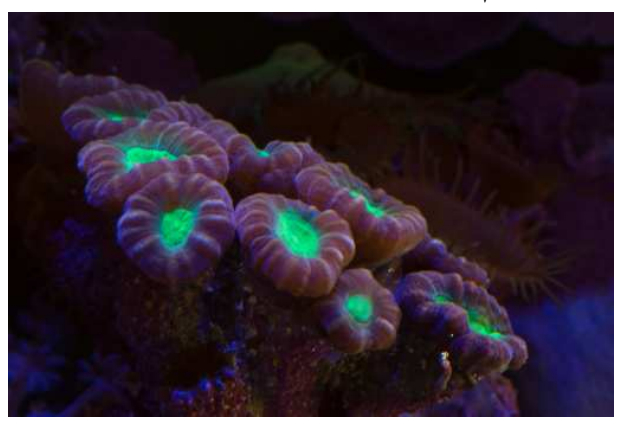

الوحدة المستخخدمـة

التصمييم الخامس

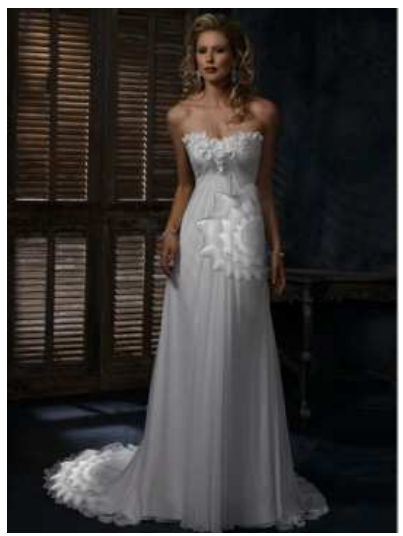

بعد إضـافة التصميهم

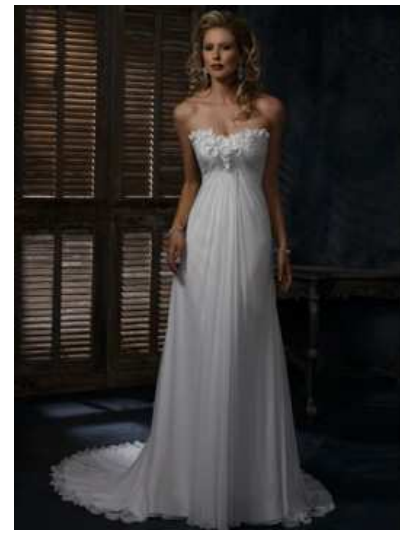

قبل إضـافة التصميم 


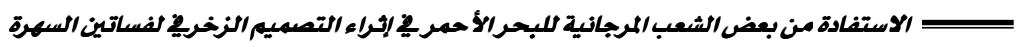

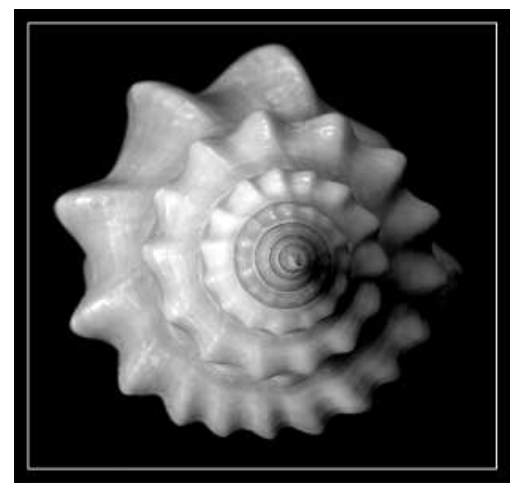

الوحدة المستتخدمـة

التصميه السادس

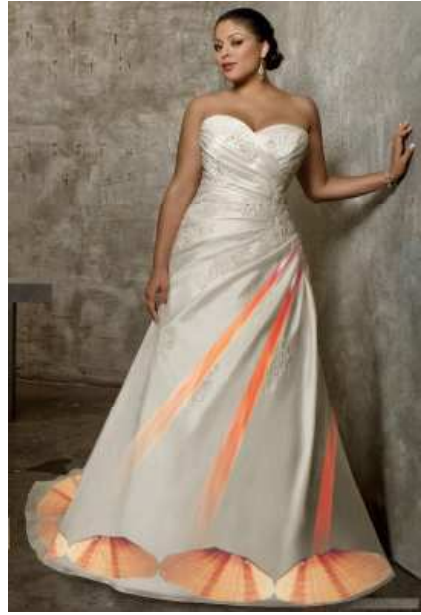

بعد إضـافة التصميهم

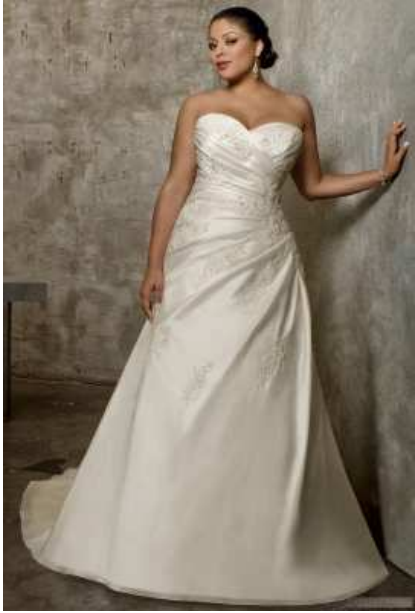

قبل إضـافة التصسيم

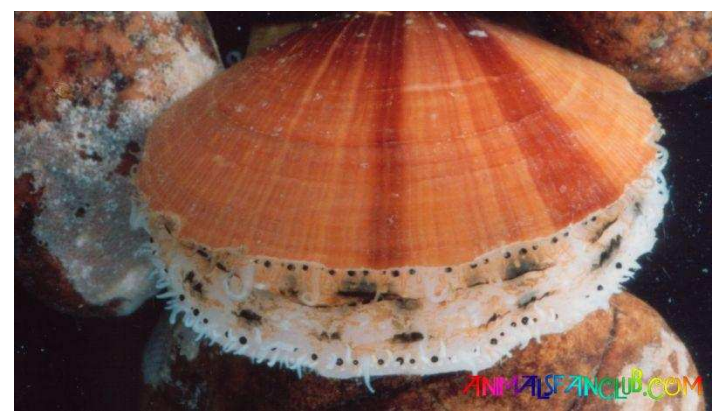

الوحدة المستخدمهة 


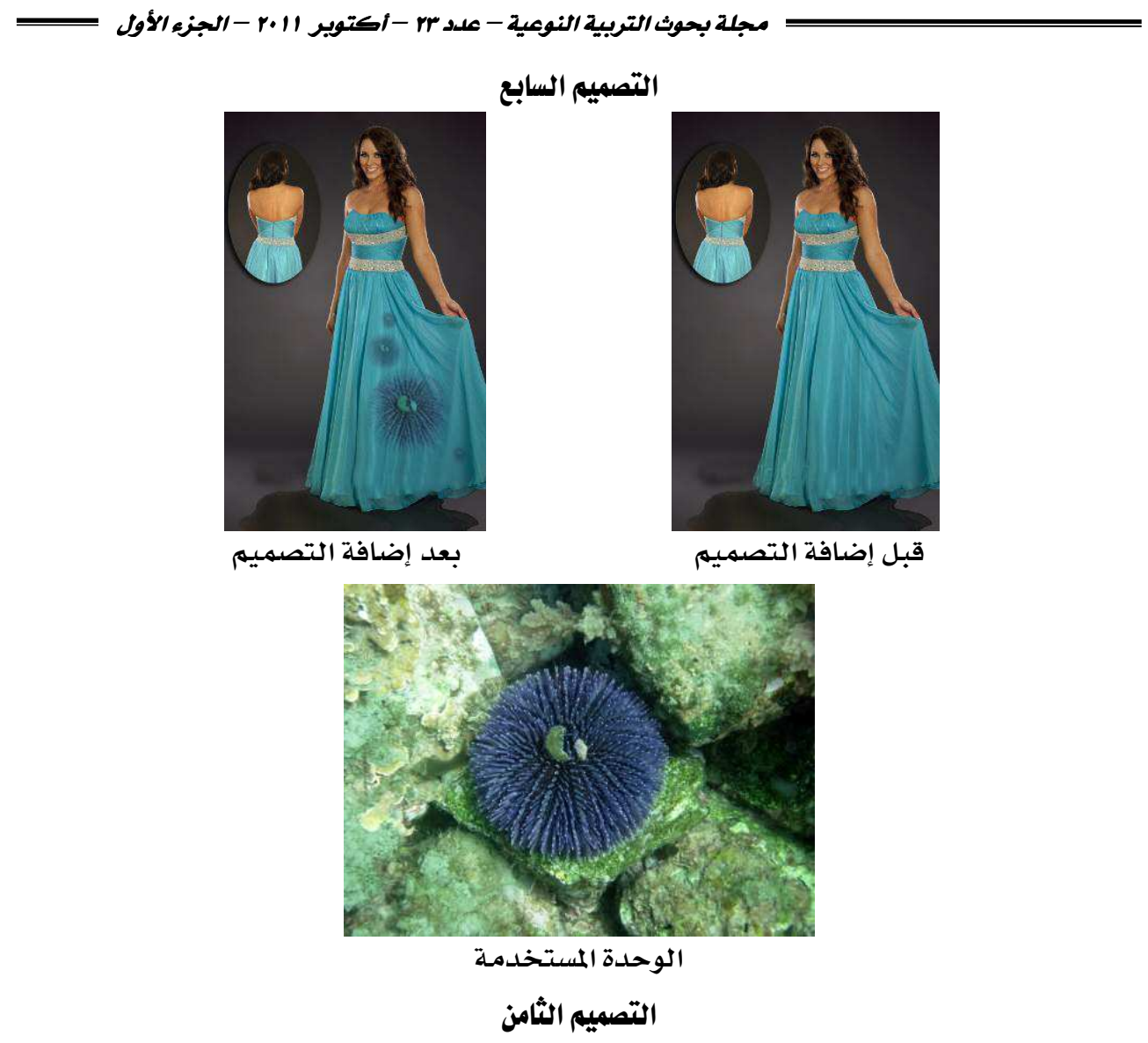

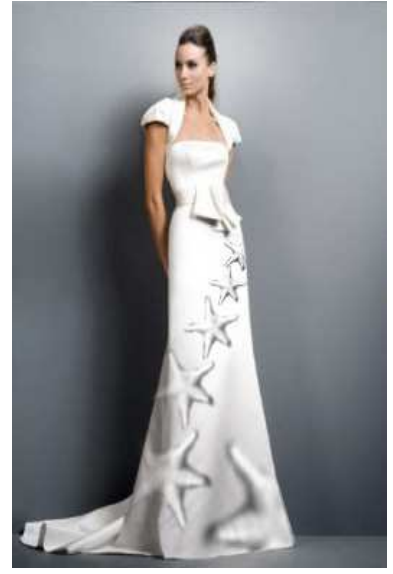

بعد إضـافة التصميهم

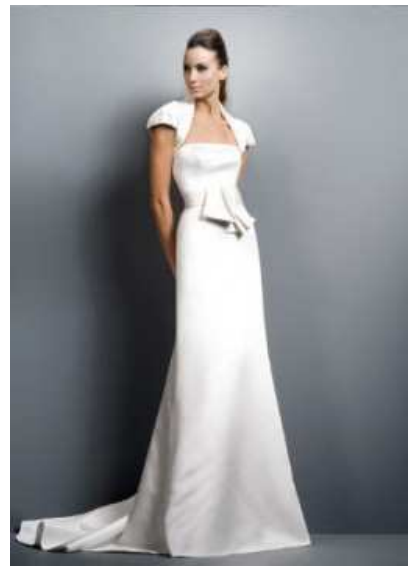

قبل إضـافة التصهيم 


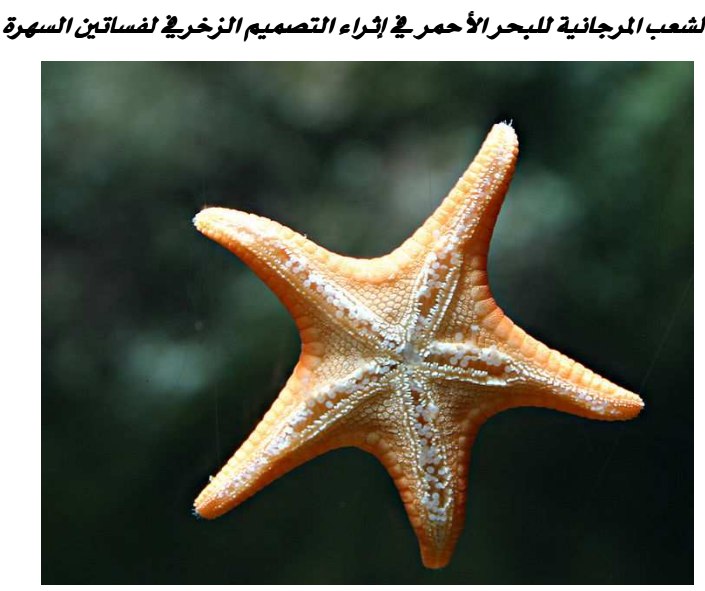

الوحدة المستخلدمـة

التصميي القاسع

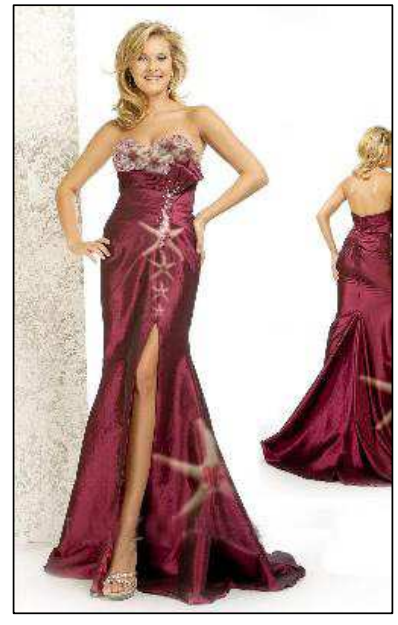

بعد إضافة التصميم

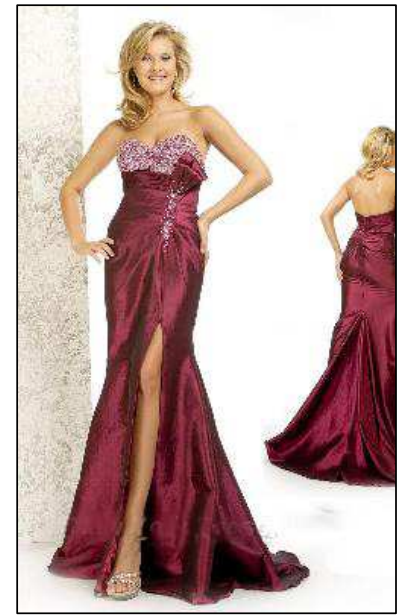

قبل إضافة التصميه

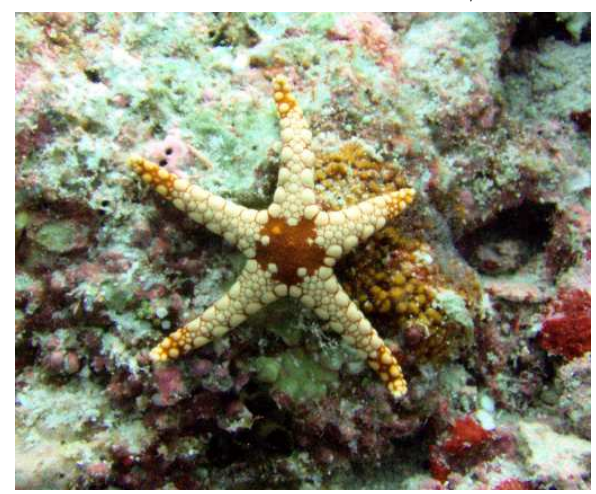

الوحدة المستخلدمـة 


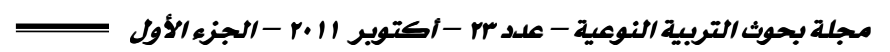

التصمييم العاشر

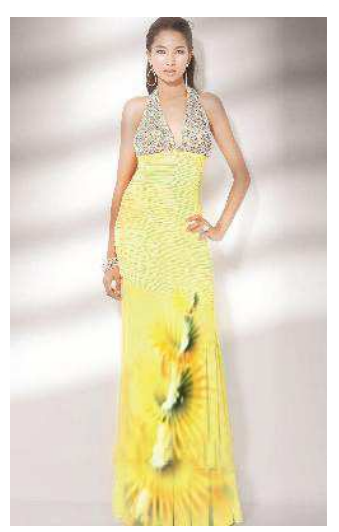

بعد إضافة التصميهم

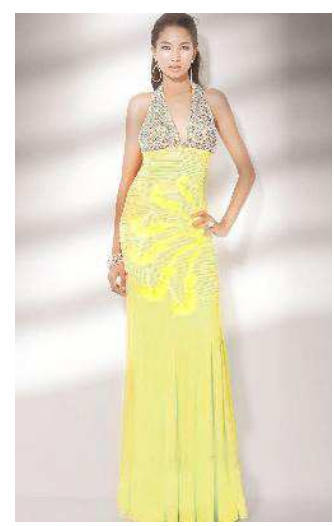

قبل إضـافة التصميم

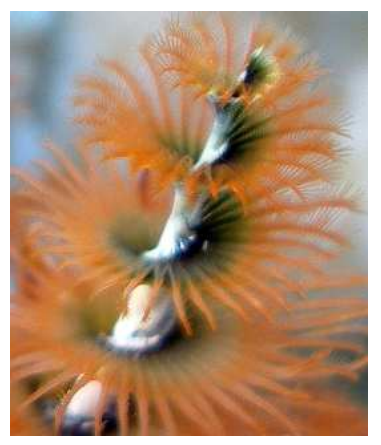

الوحدة المستخخدمة

التصميم الحادى عشر

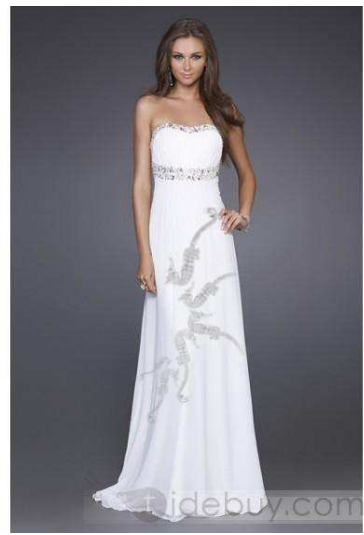

بعد إضافة التصميم

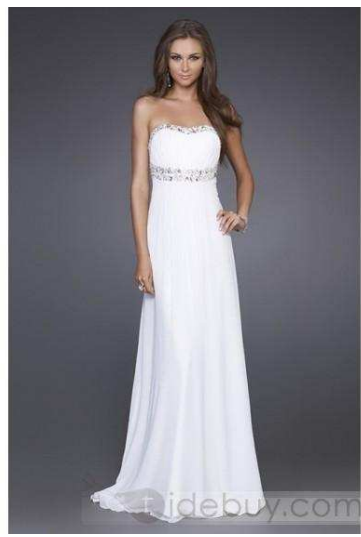

قبل إضافة التصميم 


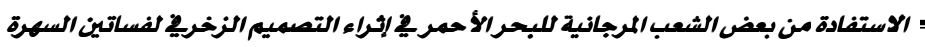

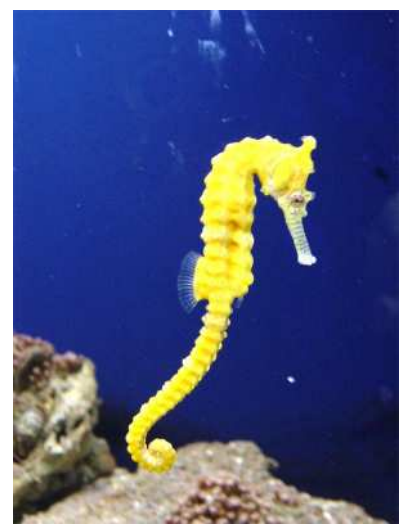

الوحلدة المستخخدمـة

التصميم الثانى عشر الترد

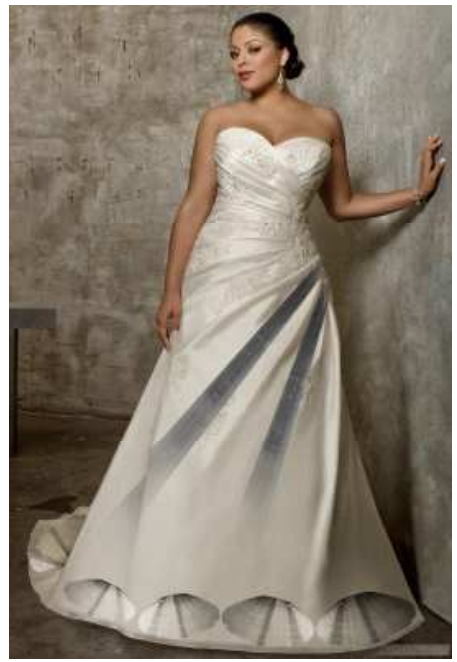

بعد إضنافة التصهيم

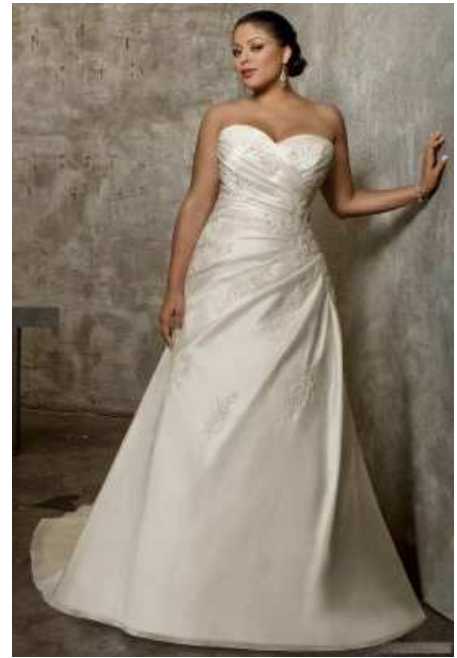

قبل إضـافة التصهيهم

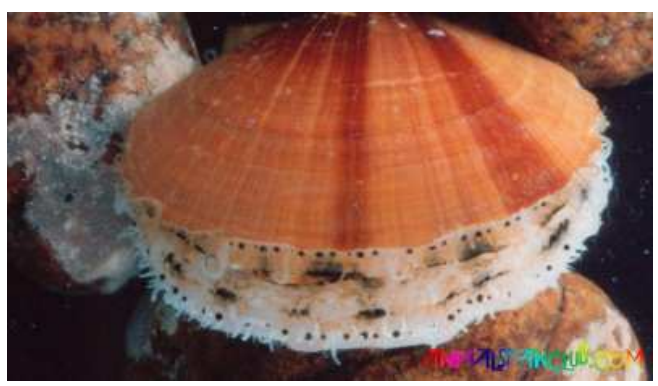

الوحدة المستخخدمـة 


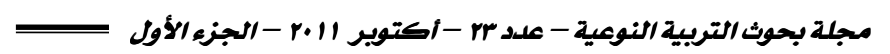

التصميي الثالث عشر
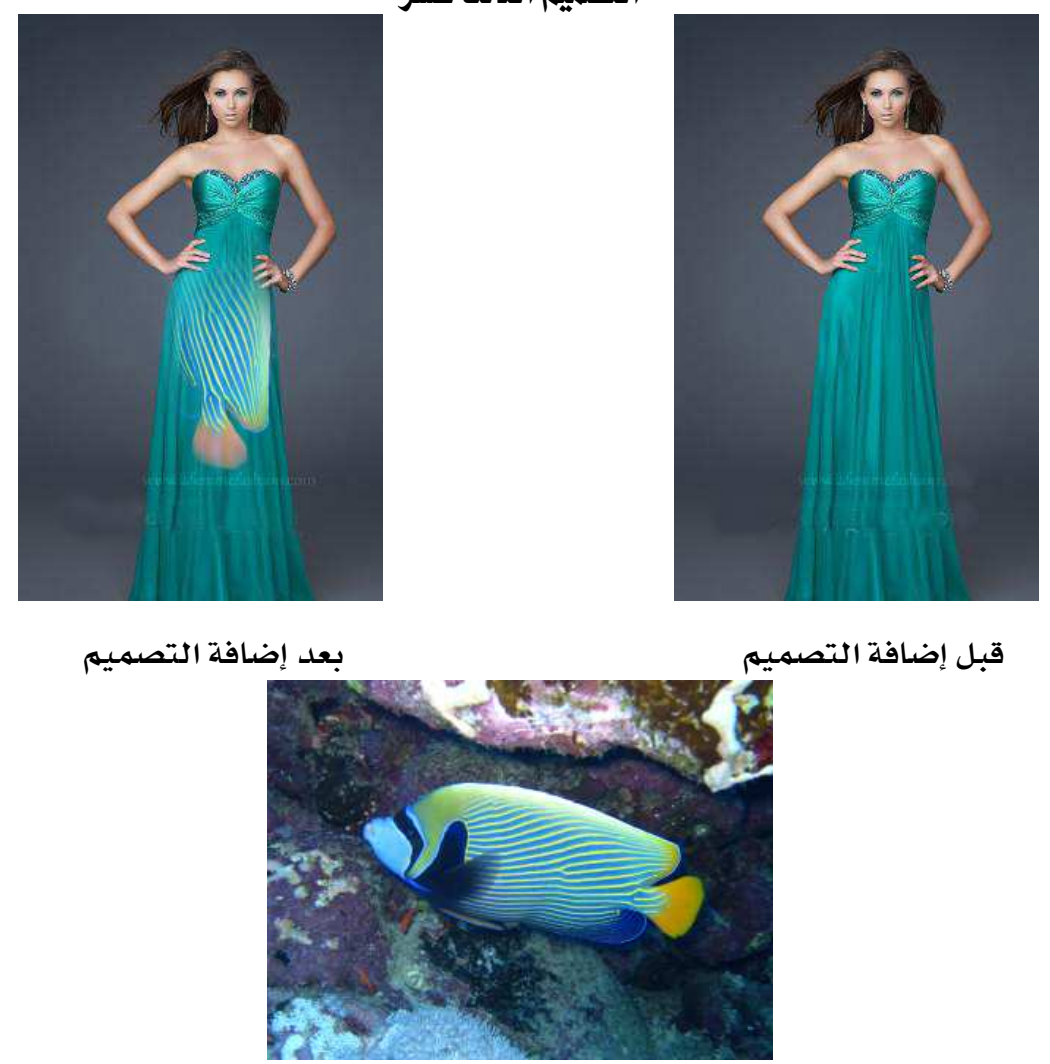

الوحلدة المستخدمة

التصميي الرابع عشر المرد

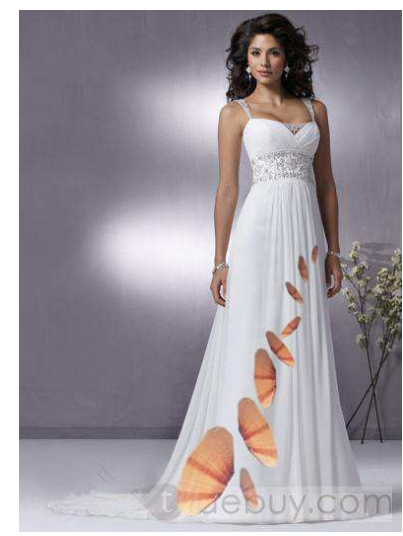

بعد إضافة التصميم

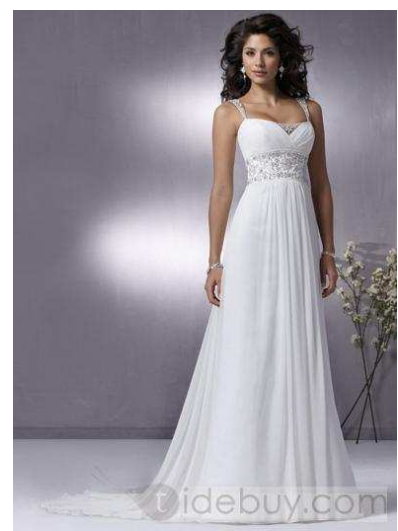

قبل إضافة التصميم 
الاستفادة من بعض الشعب المرجانية للبحر الأحمر فِ إثراء التصميم الزخرِِ لفساتين السهرة

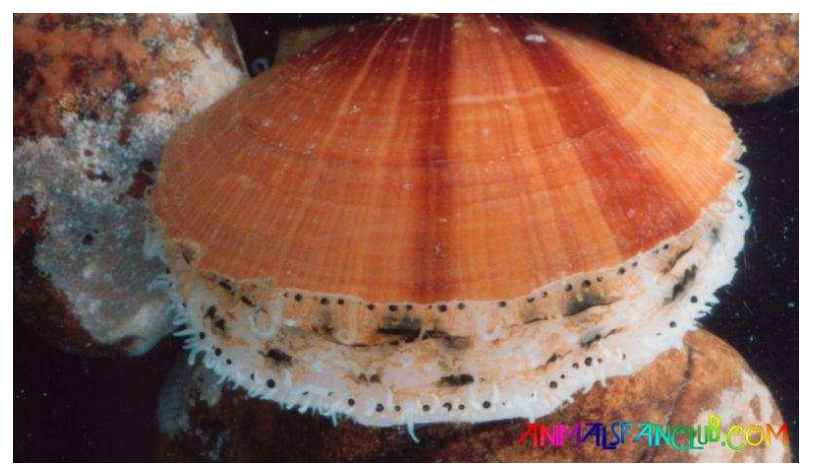

الوحدة المستخخدمـة

التصميه الخامس عشر التشحر
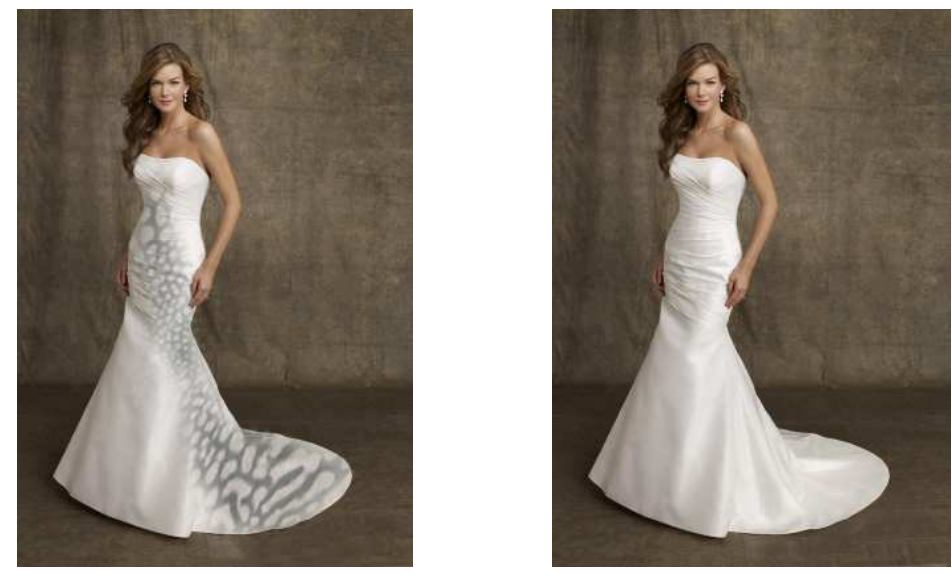

بعد إضافة التصميم

قبل إضـافة التصميم

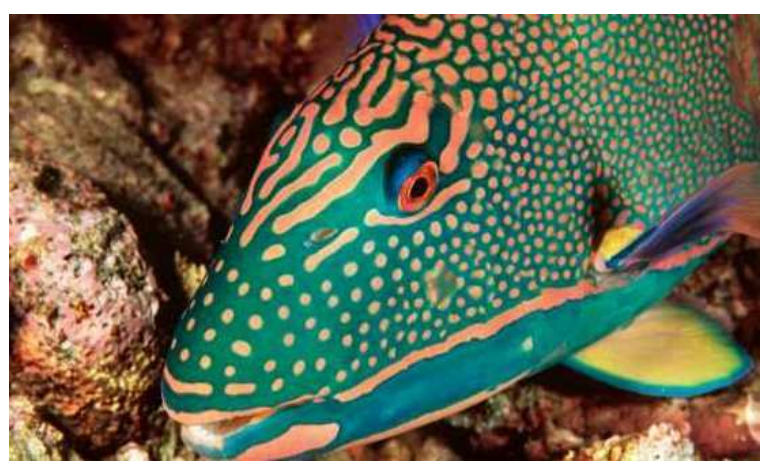

الوحدة المستخحمـة 


\section{النتائج}

الفرض الأول :

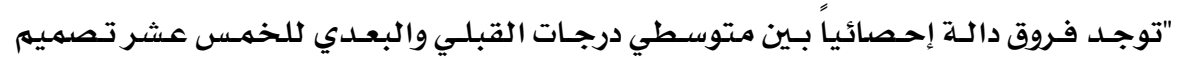

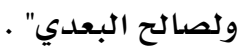

وللتحقق من هذا الفرض تم تطبيق اختبار "ت" والجدول التالي يوضح ذلك :

جدول (r) دلالة الفروق بين متوسطي درجات القبلي والبعدي للتصميه الأول

\begin{tabular}{|c|c|c|c|c|c|c|}
\hline الدلالة & قيمة (ت) & دالحرية & العينة & الانحراف & المتوسط & التصميي الأول \\
\hline \multirow{2}{*}{ لدال عند ا+,. } & \multirow{2}{*}{$\mathrm{rr}, O \Lambda$. } & \multirow{2}{*}{19} & \multirow{2}{*}{ r. } & I, var & $11, \mathrm{Vr}$. & قبلي \\
\hline & & & & - 994 & rr,gor & بعدي \\
\hline
\end{tabular}

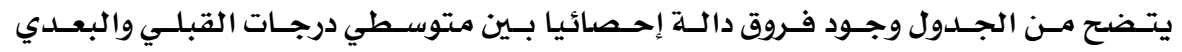

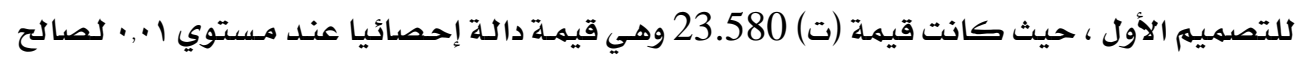
البعدي

جدول (ع) دلالة الفروق بين متوسطي درجات القبلي والبعدي للتصميم الثاني

\begin{tabular}{|c|c|c|c|c|c|c|}
\hline اللالالة & قيمة (ت) & درجيـــات & العينة & الالمعياري & الحسوسابي & الثاني الثـــيه \\
\hline \multirow{2}{*}{ لصال عند ال,. } & \multirow{2}{*}{ rv, rqu } & \multirow{2}{*}{19} & \multirow{2}{*}{ r. } & 1, rav & Ir,ruv & قبلي \\
\hline & & & & $1, \mathrm{rIA}$ & $r q, r \xi$. & بعدي \\
\hline
\end{tabular}

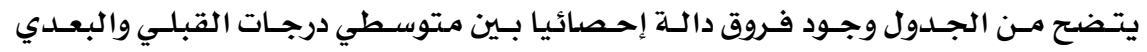

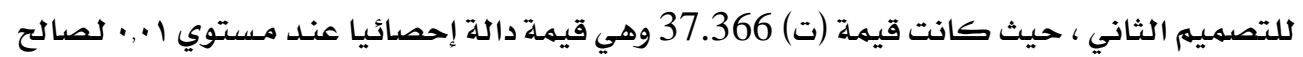
البعدي

جدول (ه) دلالة الفروق بين متوسطي درجات القبلي والبعدي للتصميم الثالث

\begin{tabular}{|c|c|c|c|c|c|c|}
\hline الدلالة & قيمة (ت) & الدرجات & العينة & الانحراف & التوسط & التصميم \\
\hline \multirow{2}{*}{ دال عند ا+,• لصالح } & \multirow{2}{*}{$r \cdot,\{T Y$} & \multirow{2}{*}{19} & \multirow{2}{*}{ r. } & $1, r 10$ & 11,170 & قبلي \\
\hline & & & & •, 109 & rT, rAY & بعدي \\
\hline
\end{tabular}

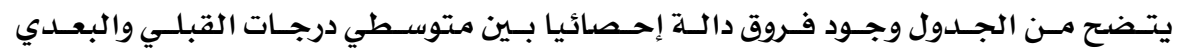

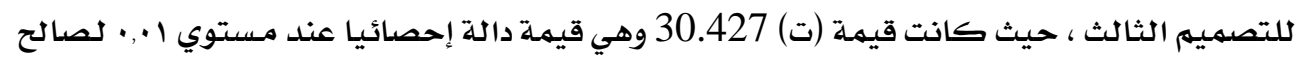
البعدي 
جدول (ج) دلالة الفروق بين متوسطي درجات القبلي والبعدي للتصميم الرابع

\begin{tabular}{|c|c|c|c|c|c|c|}
\hline الدلالة & قيمة (ت) & درجات & العينة & الالمحراف & الحتوسط & التصميه \\
\hline \multirow{2}{*}{ دال عند ا•, • لصالح البعدي } & \multirow{2}{*}{$\varepsilon \bullet, r q}$. & \multirow{2}{*}{19} & \multirow{2}{*}{ r. } & $1, \sum \forall 1$ & $|r, \cdot r|$ & قبلي \\
\hline & & & & I, rqA & YA, 70. & بعدي \\
\hline
\end{tabular}

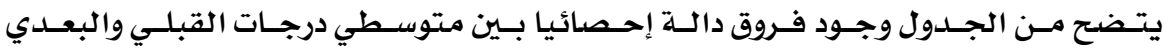

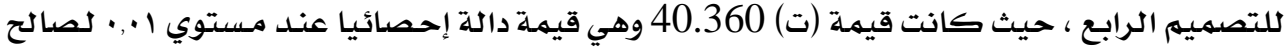

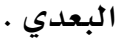

جدول (v) دلالة الفروق بين متوسطي درجات القبلي والبعدي للتصميم الخامس

\begin{tabular}{|c|c|c|c|c|c|c|}
\hline 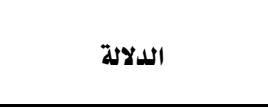 & 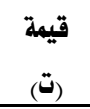 & دالعرية & العينة العة & الالمعياري & الحسابي & التصميم \\
\hline \multirow{2}{*}{ دال عند ا+,• لصالح البعدي } & \multirow{2}{*}{$r 1, T V r$} & \multirow{2}{*}{19} & \multirow{2}{*}{ r. } & $1, \Lambda \cdot r$ & $\|, \wedge \wedge$. & قبلي \\
\hline & & & & $1,0 \%$ & rr, $79 \mathrm{r}$ & بعدي \\
\hline
\end{tabular}

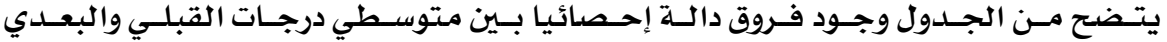

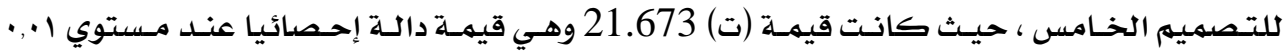

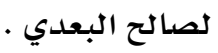

جدول (^) دلالة الفروق بين متوسطي درجات القبلي والبعدي للتصميم السادس

\begin{tabular}{|c|c|c|c|c|c|c|}
\hline الللالة & قيمة (ت) & الدرجات & العينة & الانحراف & الحسوسط الحسبي & التصميه \\
\hline \multirow{2}{*}{ دال عند ا+,• لصالح } & \multirow{2}{*}{ १A,\&F. } & \multirow{2}{*}{19} & \multirow{2}{*}{ r. } & $1, \cdot \lambda \cdot$ & 18,777 & قبلي \\
\hline & & & & $1,1 \% \cdot$ & rI,OAr & بعدي \\
\hline
\end{tabular}

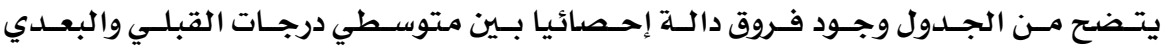

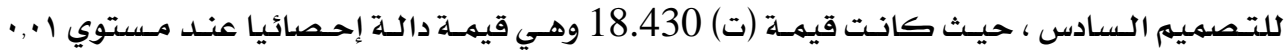

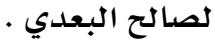

جدول (9) دلالة الفروق بين متوسطي درجات القبلي والبعدي للتصميم السابع

\begin{tabular}{|c|c|c|c|c|c|c|}
\hline الدلالة & قيمة & العرجية & العينة & الانحراف & الحسوسط & التصبيم \\
\hline \multirow{2}{*}{ دال عند اי,, لصالح } & \multirow{2}{*}{$r r, 901$} & \multirow{2}{*}{19} & \multirow{2}{*}{ r. } & $1, .19$ & Ir,orr & قبلي \\
\hline & & & & $1,71$. & rq, ro. & بعدي \\
\hline
\end{tabular}


مجلة بحوث التربية النوعية - عدد rr - أكتوبر ll.r - الجزءء الأول

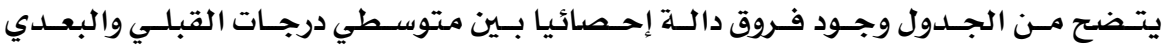

للتصميهم السـابع ، حيث كانت قيمة (ت) 33.958 وهي قيمة دالة إحصائيا عند مستوي ا •. • لصسالح البعدي

جدول ( • (1) دلالة الفروق بين متوسطي درجات القبلي والبعدي للتصميم الثامن

\begin{tabular}{|c|c|c|c|c|c|c|}
\hline الدلالة & قيمة (ت) & درجــات & العينة & الانحراف & المتوسـط & الثامن الثمييم \\
\hline \multirow{2}{*}{ لصال عند اי,. } & \multirow{2}{*}{$r I, r \cdot r$} & \multirow{2}{*}{19} & \multirow{2}{*}{ r. } & $1,0 \leqslant 7$ & Ir,rrs & قبلي \\
\hline & & & & $1, \cdot 01$ & $r r, q \Lambda 1$ & بعدي \\
\hline
\end{tabular}

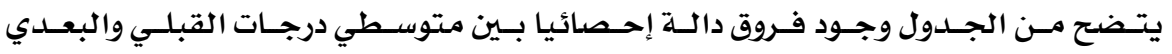

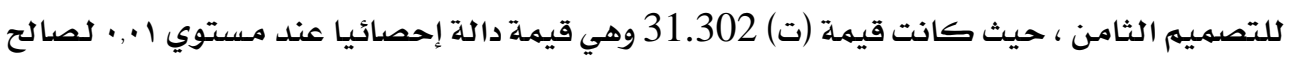
البعدي

جلدول (11) دلالة الفروق بين متوسطي درجات القبلي والبعدي للتصميم التاسع

\begin{tabular}{|c|c|c|c|c|c|c|}
\hline الدلالة & قيمة & الحرجية & العينة & $\begin{array}{l}\text { الانحراف } \\
\text { المعياري } \\
\end{array}$ & المتوسط الحسابي & التصميي \\
\hline \multirow{2}{*}{ دال عند ا+,• لصالح } & \multirow{2}{*}{ r\&, YO. } & \multirow{2}{*}{19} & \multirow{2}{*}{ r. } & 1 , ror & 11, 7ov & قبلي \\
\hline & & & & I, YMA & r\&, YA. & بعدي \\
\hline
\end{tabular}

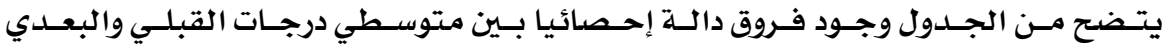
للتصميهم التاسـع ، حيث كانت قيمـة (ت) 34.250 وهي قيمة دالة إحصائيا عند مستوي ا •. • لصسالح البعدي

جدول (r ا ) دلالة الفروق بين متوسطي درجات القبلي والبعدي للتصميهم العاشر

\begin{tabular}{|c|c|c|c|c|c|c|}
\hline الدلالة & قيمة (ت) & درجات & العينة & الانحراف & المتوسط & التصميي \\
\hline \multirow{2}{*}{ دال عند ا+,• لصالح } & \multirow{2}{*}{$r q, \cdot \cdot r$} & \multirow{2}{*}{19} & \multirow{2}{*}{ r. } & $1, \mathrm{HIE}$ & Ir, rar & قبلي \\
\hline & & & & 1,ro7 & ro,Al. & بعلدي \\
\hline
\end{tabular}

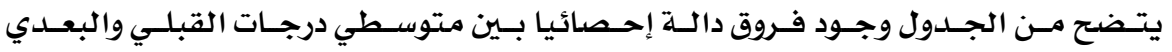
للتصميهم العـاشر ، حيث كانت قيمهة (ت) 29.002 وهي قيمـة دالة إحصائيا عند مستوي ا •. • لصالح البعدي 
جدول (rا ) دلالة الفروق بين متوسطي درجات القبلي والبعدي للتصميم الحادي عشر

\begin{tabular}{|c|c|c|c|c|c|c|}
\hline الدلالة & $\begin{array}{l}\text { قيهة } \\
\text { (ت) } \\
\end{array}$ & الحرجية & العينة & الانحراف & التوسط & التصميم الحادي \\
\hline \multirow{2}{*}{ دال عند ا+,• لصالح } & \multirow{2}{*}{ YA, IVT } & \multirow{2}{*}{19} & \multirow{2}{*}{ r. } & $1,79 \varepsilon$ & II, vor & قبلي \\
\hline & & & & $1,+47$ & $r r, q \leqslant r$ & بعدي \\
\hline
\end{tabular}

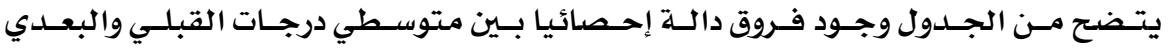

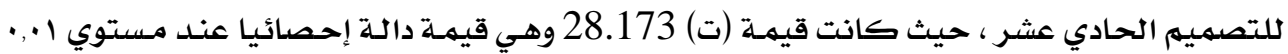

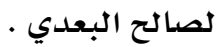

جدول (ع ا ) دلالة الفروق بين متوسطي درجات القبلي والبعدي للتصميم الثاني عشر

\begin{tabular}{|c|c|c|c|c|c|c|}
\hline الدلالة & قيمة & العرجية & العينة & الانحراف & التوسط & التصميم \\
\hline \multirow{2}{*}{ دال عند ا•,• لصالح } & \multirow{2}{*}{ rr, rI } & \multirow{2}{*}{19} & \multirow{2}{*}{ r. } & $1,+\wedge$. & $|r, \cdot \Delta|$ & قبلي \\
\hline & & & & $1, \cdots 0$ & rr,orr & بعدي \\
\hline
\end{tabular}

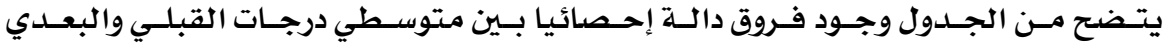

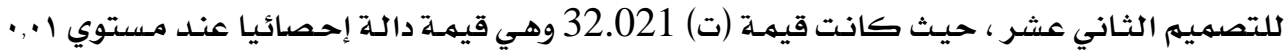
لصالح البعدي •

جدول (10) دلالة الفروق بين متوسطي درجات القبلي والبعدي للتصميم الثالث عشر

\begin{tabular}{|c|c|c|c|c|c|c|}
\hline الدلالة & قيعة (ت) & الرجات & العينة & الانحراف & الحتوسط & الثاثث عشر \\
\hline \multirow{2}{*}{ دال عند ال, • لصالح } & \multirow{2}{*}{ ro, oor } & \multirow{2}{*}{19} & \multirow{2}{*}{ r. } & $1,09 r$ & $1 r, 7 \wedge 0$ & قبلي \\
\hline & & & & 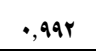 & ro, rY & بعدي \\
\hline
\end{tabular}

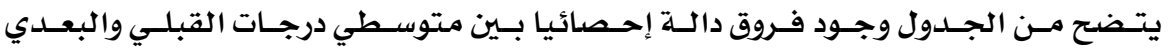

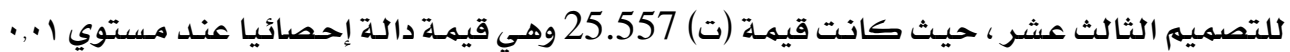

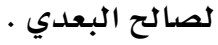

جدول (17) دلالة الفروق بين متوسطي درجات القبلي والبعدي للتصميم الرابع عشر

\begin{tabular}{|c|c|c|c|c|c|c|}
\hline الدلالة & قيمة (ت) & الدرجية & العينة & الانحراف & الحسوسط & الترابع عشر \\
\hline \multirow{2}{*}{ دال عند ا.,• لصالح } & \multirow{2}{*}{$r \xi, 7 r_{.}$} & \multirow{2}{*}{19} & \multirow{2}{*}{ r. } & $1, \cdot 14$ & $1 r, 0 \cdot \lambda$ & قبلي \\
\hline & & & & $1, \cdot \pi$ & Tr, & بعدي \\
\hline
\end{tabular}


مجلة بحوث التربية النوعية - عدد rr - أكتوبر ll.r - الجزءء الأول

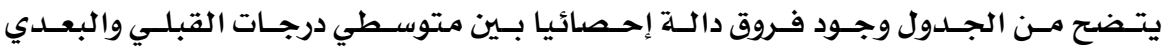

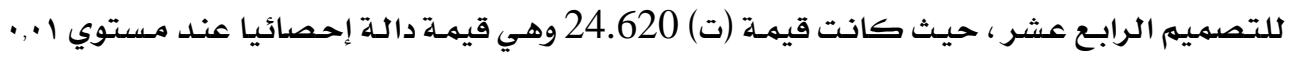
لـالح البعدي

جدول (IV) دلالة الفروق بين متوسطي درجات القبلي والبعدي للتصميهم الخامس عشر

\begin{tabular}{|c|c|c|c|c|c|c|}
\hline الدلالة & 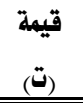 & الحرجة & العينة & الانحراف & المتوسط & التامس عشير \\
\hline \multirow{2}{*}{ دال عند ا+,• لصالح البعدي } & \multirow{2}{*}{ rq, $\cdot$ r. } & \multirow{2}{*}{19} & \multirow{2}{*}{ r. } & $1, \cdots 1$ & $1 r, v \cdot q$ & قبلي \\
\hline & & & & 1, rrY & $r \varepsilon, \& V \cdot$ & بعلدي \\
\hline
\end{tabular}

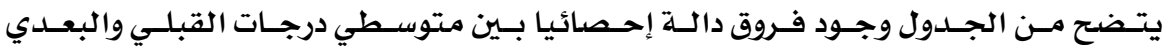

للتصميهم الخامس عشر ، حيث كانت قيمة (ت) 29.030 وهي قيمـة دالة إحصائيا عندـ مسستوي 1 .,. لصالح البعدي الفرض الثاني :

توجد فروق ذات دلالنة إحصائية بين الخمس عشر تصميهم وفقا لأراء المحكمـين .

وللتحقق مـن هـذا الفـرض تم حسسـاب تحليـل التبـاين لمتوسط درجـات الخهـس عشـر تصهيهم والجدول التالي يوضح ذلك :

جدول (1 ا ) تحليل التباين لمتوسط درجات الخمس عشر تصميه

\begin{tabular}{|c|c|c|c|c|c|}
\hline الدلالة & قيية (ف) & درجات الحرية & متوسط المربعات & مجموع المربعات & \\
\hline \multirow{3}{*}{ 1.,• دال } & \multirow{2}{*}{ OV,qAr } & 18 & vr,ovs & $1 \cdot 17, \cdot 10$ & بين المجهوعات \\
\hline & & rao & I, rTA & rAl, rar & داخل المجموعات \\
\hline & & rqq & & IETV,rYV & المجموع \\
\hline
\end{tabular}

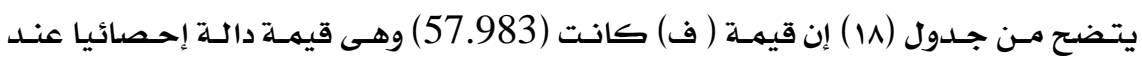

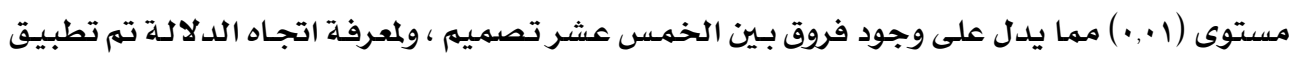

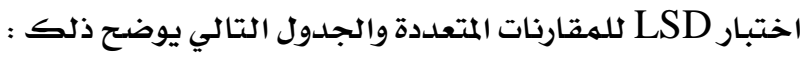


الاستفادة من بعض الشعب المرجانية للبحر الأحمر فِ إثراء التصميم الزخرِِ لفساتين السهرة

جدول بالعرض 
من الجدول السابق يتضح أن :

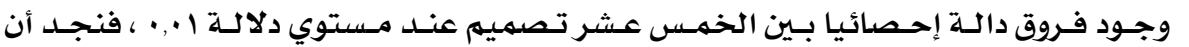

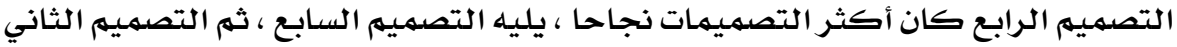

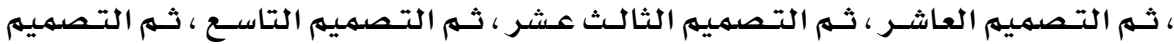

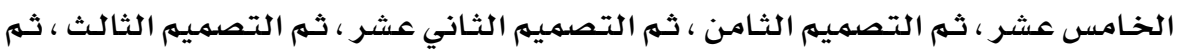

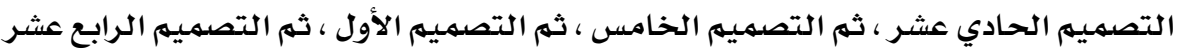
، وأخيرا التصميم السادس .

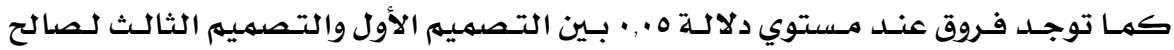

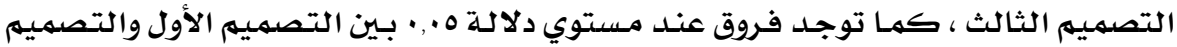

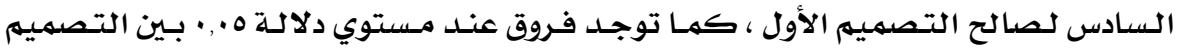

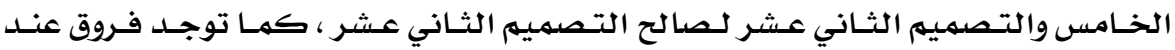

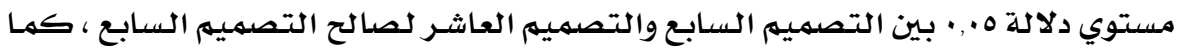

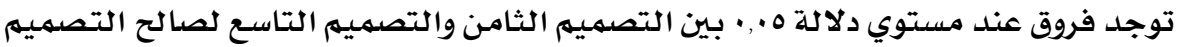

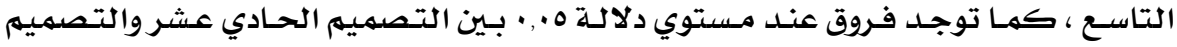

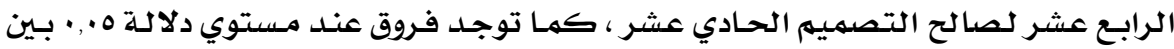

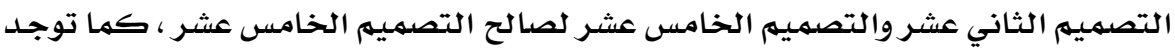

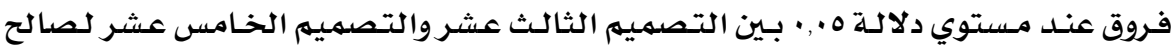

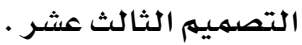

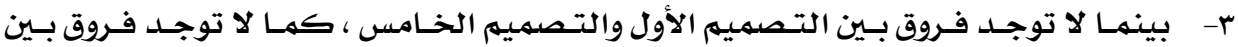

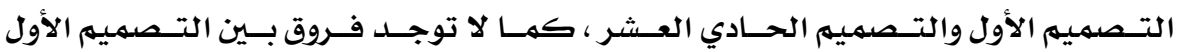

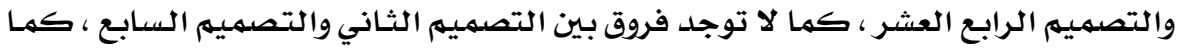

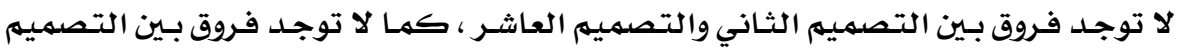

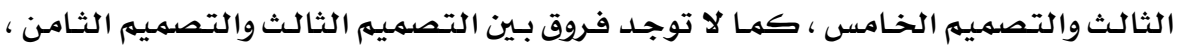

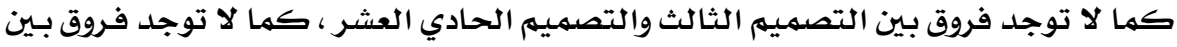

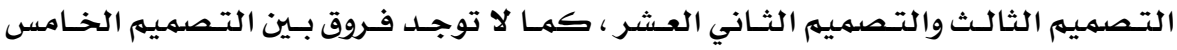

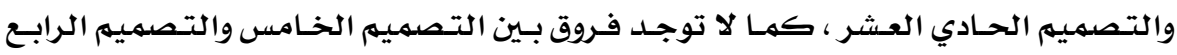

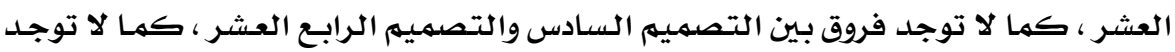

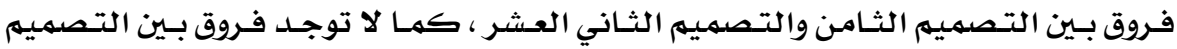

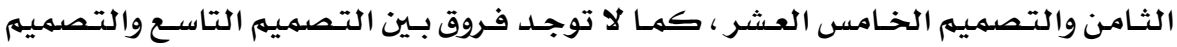

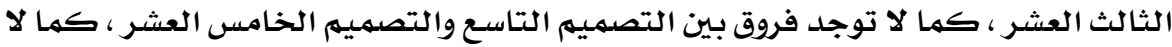

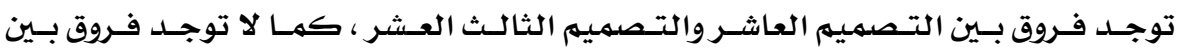

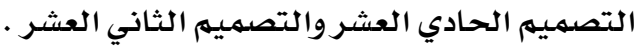
والشكل التالي يوضح ذلك : 


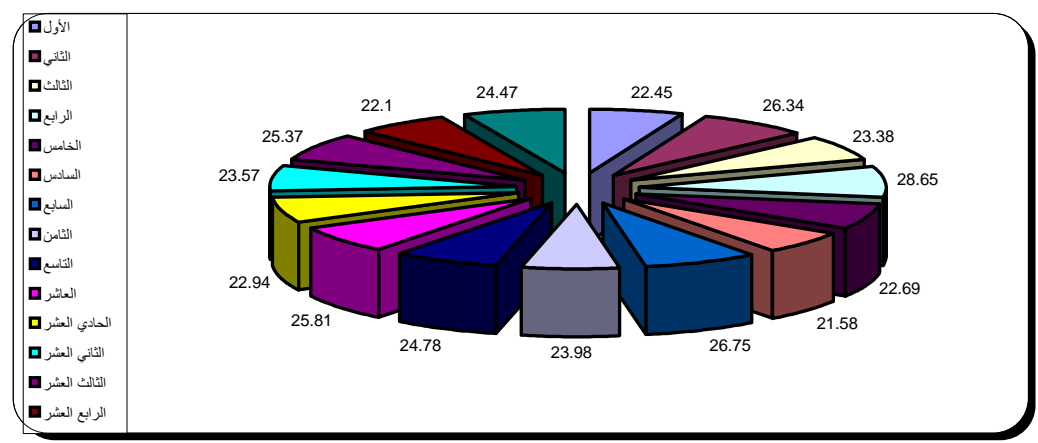

$$
\text { شكل (r) يوضـح الفروق بين الخمس عشر تصميم }
$$

جدول يوضـح تكرارات ونسب إجـابات المحكمـين لجميع بنود التصميمـات المقترحة

\begin{tabular}{|c|c|c|c|c|c|c|c|c|c|c|c|c|}
\hline \multicolumn{6}{|c|}{ التصميه رقم r } & \multicolumn{6}{|c|}{ التصميم رقم 1} & \multirow{3}{*}{ A } \\
\hline \multicolumn{3}{|c|}{ النسبة./ } & \multicolumn{3}{|c|}{ العدد } & \multicolumn{3}{|c|}{ النسبة/\% } & \multicolumn{3}{|c|}{ العدد } & \\
\hline غلائم & حلد ما & ملائم & غلائم & حلد ما & ملائم & غلائم & حلد ما & ملائم & غيائم & حلد ما & ملائم & \\
\hline$\%$ & $\%$ & $\% 9$. & 1 & 1 & 11 & $\% 10$ & $\%$ r. & $\% 00$ & $r$ & 7 & 11 & -1 \\
\hline$\%$ & $\%$ & $\% 90$ & - & 1 & 19 & $\% 10$ & $\%$ ro & $\% .9$. & $r$ & 0 & ir & $-r$ \\
\hline$\%$ & $\%$ & $\% . \wedge 0$ & 1 & $r$ & iv & $\% 10$ & $\%$. & $\% .70$ & $r$ & $\varepsilon$ & ir & -r \\
\hline$\%$ & $\% 10$ & $\%$ vo & $r$ & $r$ & 10 & $\%$ & $\% 10$ & $\%$. & 1 & $r$ & 17 & ك \\
\hline$\%$ & $\%$ & $\% \wedge$. & $r$ & $r$ & 17 & $\%$ & $\% 10$ & $\%$ Yo & $r$ & $r$ & 10 & - 0 \\
\hline$\%$ & $\%$. & $\% v$. & $r$ & $\varepsilon$ & $1 \varepsilon$ & $\%$ & $\%$ & $\%$ & r & 7 & ir & -7 \\
\hline$\%$ & $\%$ & $\% \wedge 0$ & 1 & $r$ & iv & $\%$ & $\%$ ro & $\% 00$ & $r$ & $\checkmark$ & 11 & $-Y$ \\
\hline$\%$ & $\% 10$ & $\%$ vo & $r$ & $r$ & 10 & $\% r$. & $\% 10$ & $\% .70$ & $\xi$ & $r$ & ir & $-\Lambda$ \\
\hline$\%$ & $\%$ & $\% \wedge$. & $r$ & $r$ & 17 & $\%$ & $\%$ r. & $\%$. & $r$ & $\xi$ & $1 \varepsilon$ & -9 \\
\hline$\%$ & $\%$ & $\% \wedge 0$ & $r$ & 1 & iv & $\%$ & $\% 10$ & $\%$ Yo & $r$ & $r$ & 10 & -1. \\
\hline
\end{tabular}




\begin{tabular}{|c|c|c|c|c|c|c|c|c|c|c|c|c|}
\hline \multicolumn{13}{|c|}{ 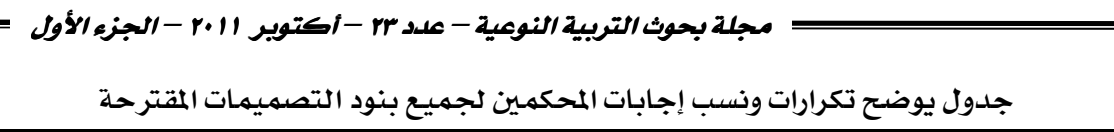 } \\
\hline \multicolumn{6}{|c|}{ التصمييم رقم ع } & \multicolumn{6}{|c|}{ التصميه رقم r } & \multirow{3}{*}{ P } \\
\hline \multicolumn{3}{|c|}{ النسبة./ } & \multicolumn{3}{|c|}{ العدد } & \multicolumn{3}{|c|}{ النسبة./ } & \multicolumn{3}{|c|}{ العدد } & \\
\hline غلائم & إلي حلد & ملائم & غلائم & حلد ما & ملائم & غيائم & إلي ما & ملائم & غلائم & حلد ما & ملائم & \\
\hline$\%$ & $\%$ & $\% 1 \cdots$ & - & . & $r \cdot$ & $\%$ & $\%$ ro & $\% v$. & 1 & 0 & 18 & -1 \\
\hline$\%$ & $\%$ & $\% 90$ & • & 1 & 19 & $\%$ & $\% 10$ & $\%$. & 1 & $r$ & 17 & $-r$ \\
\hline$\%$ & $\%$ & $\%$ & - & - & r. & $\% 10$ & $\%$ r. & $\% 70$ & $r$ & $\varepsilon$ & ir & r- \\
\hline$\% 0$ & $\%$ & $\% 9$. & 1 & 1 & 11 & $\% 10$ & $\% 10$ & $\% v$. & $r$ & $r$ & 18 & $\varepsilon$ \\
\hline$\%$ & $\%$ & $\% .10$ & $r$ & 1 & iv & $\%$ & $\%$ ro & $\%$. & • & 0 & 10 & -0 \\
\hline$\%$ & $\%$ & $\% 90$ & • & 1 & 19 & $\%$ & $\%$ & $\%$. & $r$ & 7 & ir & -7 \\
\hline$\%$ & $\%$ & $\% 9$. & • & $r$ & 11 & $\% 10$ & $\% r$ & $\% 70$ & $r$ & $\varepsilon$ & ir & $-y$ \\
\hline$\% 0$ & $\% 10$ & $\% \Lambda^{\circ}$ & 1 & $r$ & 17 & $\%$ & $\%$ & $\% v$. & $r$ & $\xi$ & $1 \varepsilon$ & $-\Lambda$ \\
\hline$\%$ & $\%$ & $\% 90$ & - & 1 & 19 & $\%$ & $\% 10$ & $\%$. & $r$ & $r$ & 10 & -9 \\
\hline$\%$ & $\%$ & $\% 9$. & 1 & 1 & 11 & $\% 10$ & $\% \mu$. & $\% 00$ & $r$ & 7 & 11 & -1. \\
\hline
\end{tabular}

جدول يوضـح تكرارات ونسب إجابات المحكمـين لجميع بنود التصميمات المقترحة

\begin{tabular}{|c|c|c|c|c|c|c|c|c|c|c|c|c|}
\hline \multicolumn{6}{|c|}{ التصميم رقم 7} & \multicolumn{6}{|c|}{ التصميم رقم ه } & \multirow{3}{*}{ P } \\
\hline \multicolumn{3}{|c|}{ النسبة. } & \multicolumn{3}{|c|}{ العدد } & \multicolumn{3}{|c|}{ النسبة.| } & \multicolumn{3}{|c|}{ العدد } & \\
\hline غلائم & حلد ما & ملائم & غلائم & حلد ما & ملائم & ملئم & حلد ما & ملائم & ملائم & حلد ما & ملائم & \\
\hline$\%$ & $\%$ & $\% 0$. & $\xi$ & 7 & 1. & $\%$ & $\%$ ro & $\% 70$ & $r$ & 0 & Ir & -1 \\
\hline$\%$ & $\%$ ro & $\% 00$ & $\varepsilon$ & 0 & 11 & $\%$ & $\% 10$ & $\% 70$ & $\varepsilon$ & $r$ & Ir & - r \\
\hline$\%$ & $\%$ \% & $\%$ & 1 & $r$ & ir & $\%$ & $\%$ & $\%$. & 1 & $\varepsilon$ & 10 & -r \\
\hline$\%$ & $\%$ & $\% 00$ & 1 & $\Lambda$ & 11 & $\%$ & $\% 10$ & $\%$ • & 1 & $r$ & 17 & $\varepsilon$ \\
\hline$\%$ & $\% \mathrm{r} \cdot$ & $\%$ & $r$ & 7 & Ir & $\%$ & $\%$ & $\% 10$ & 1 & $r$ & iv & ـ \\
\hline$\%$ & $\%$ & $\% 70$ & 1 & 7 & ir & $\%$ & $\%$ & $\%$ & $r$ & 7 & ir & -7 \\
\hline$\%$ & $\%$ ro & $\% v$. & 1 & 0 & $1 \xi$ & $\% 10$ & $\%$ & $\% .70$ & $r$ & $\varepsilon$ & Ir & $-y$ \\
\hline$\%$ & $\% 10$ & $\%$ Yo & $r$ & $r$ & 10 & $\%$ & $\%$ & $\%$ & $r$ & 7 & ir & $-\Lambda$ \\
\hline$\%$ ro & $\%$ r. & $\% 00$ & 0 & $\varepsilon$ & 11 & $\%$ ro & $\%$ ro & $\%$ & 0 & 0 & 1. & -9 \\
\hline$\%$ & $\% \mu$ & $\%$ & $\xi$ & 7 & 1. & $\% 1$ & $\%$ & $\% v$. & $r$ & $\varepsilon$ & $1 \varepsilon$ & -1. \\
\hline
\end{tabular}


الاستفادة من بعض الشعب المرجانية للبحر الأحمر فِ إثراء التصميم الزخرِفِ لفساتين السهرة

جدول يوضـح تكرارات ونسب إجابات المحكمـين لجميـع بنود التصميمـات المقترحة

\begin{tabular}{|c|c|c|c|c|c|c|c|c|c|c|c|c|}
\hline & \multicolumn{5}{|c|}{ التصميم رقم 1} & \multicolumn{6}{|c|}{ التصميم رقم V } & \\
\hline \multicolumn{3}{|c|}{ النسبة|| } & \multicolumn{3}{|c|}{ العدد } & \multicolumn{3}{|c|}{ النسبة./ } & \multicolumn{3}{|c|}{ العدد } & \\
\hline ملائم & حلد ما & ملائم & غيائم & حلد إلي & ملائم & غلائم & حلد إلي & ملائم & غلائم & حلد إلي & ملائم & \\
\hline$\%$ & $\%$ ro & $\% v$. & 1 & 0 & $1 \varepsilon$ & $\%$ & $\%$ & $\% 90$ & . & 1 & 19 & -1 \\
\hline$\%$ & $\%$ & $\% v$. & $r$ & $\xi$ & $1 \xi$ & $\%$ & $\%$ & $\% 9$. & 1 & 1 & 11 & - \\
\hline$\%$ & $\% 10$ & $\% \wedge$. & 1 & $r$ & 17 & $\%$ & $\% 1$. & $\% \wedge 0$ & 1 & $r$ & iv & r \\
\hline$\% 10$ & $\%$ & $\%$ vo & $r$ & $r$ & 10 & $\%$ & $\%$ & $\% 90$ & - & 1 & 19 & $\varepsilon$ \\
\hline$\%$ & $\%$ & $\% \wedge 0$ & 1 & $r$ & iv & $\%$ & $\%$ & $\% 9$. & 1 & 1 & IA & - 0 \\
\hline$\% 10$ & $\% 10$ & $\%$. & $r$ & $r$ & $1 \xi$ & $\%$ & $\%$ & $\% 90$ & . & 1 & 19 & -7 \\
\hline$\% 10$ & $\%$ ro & $\%$ & $r$ & 0 & ir & $\%$ & $\%$ & $\% 9$. & 1 & 1 & 11 & $-Y$ \\
\hline$\%$ & $\%$ & $\% 70$ & 1 & 7 & ir & $\%$ & $\%$ & $\%$ & - & - & r. & $-\Lambda$ \\
\hline$\% 10$ & $\%$ & $\%$ Yo & $r$ & $r$ & 10 & $\%$ & $\%$ & $\% 9$. & 1 & 1 & 11 & -9 \\
\hline$\%$ & $\% 10$ & $\% \wedge$. & 1 & $r$ & 17 & $\%$ & $\%$. & $\%$. 10 & 1 & $r$ & iv & -1. \\
\hline
\end{tabular}

جدول يوضـح تكرارات ونسب إجـابات المحكمـين لجميع بنود التصميمات المقترحة

\begin{tabular}{|c|c|c|c|c|c|c|c|c|c|c|c|c|}
\hline \multicolumn{6}{|c|}{ التصميه رقه · } & \multicolumn{6}{|c|}{ التصميي رقم 9} & \multirow{3}{*}{$\rightarrow$} \\
\hline \multicolumn{3}{|c|}{ النسبة./ } & \multicolumn{3}{|c|}{ العدد } & \multicolumn{3}{|c|}{ النسبة./ } & \multicolumn{3}{|c|}{ العدد } & \\
\hline فلائم & حلد ما & ملائم & فيائم & حلد ما & ملائم & غلائم & حلد ما & ملائم & فيائم & حلد ما & ملائم & \\
\hline$\%$ & $\% 10$ & $\%$ vo & $r$ & $r$ & 10 & $\%$ & $\%$ ro & $\%$. & 1 & 0 & $1 \varepsilon$ & -1 \\
\hline$\%$ & $\%$ r. & $\%$. & . & $\varepsilon$ & 17 & $\%$ & $\%$ & $\%$. & . & $\xi$ & 17 & $-r$ \\
\hline$\%$ & $\%$ & $\% \wedge 0$ & 1 & $r$ & iv & $\%$ & $\% \mu \cdot$ & $\% 70$ & 1 & 7 & ir & r \\
\hline$\%$ & $\% 10$ & $\%$ Yo & r & $r$ & 10 & $\%$ & $\%$ & $\%$. & $r$ & $\varepsilon$ & $1 \varepsilon$ & كـ \\
\hline$\% 10$ & $\%$ & $\%$ • & $r$ & 1 & 17 & $\% r^{*}$ & $\%$ & $\%$. & $\varepsilon$ & $r$ & $1 \xi$ & هـ \\
\hline$\%$ & $\%$ & $\% \wedge 0$ & 1 & $r$ & iv & $\%$ & $\% 10$ & $\%$. & $r$ & $r$ & 10 & -7 \\
\hline$\%$ & $\%$ & $\%$ ro & 1 & $\varepsilon$ & 10 & $\%$ & $\% 10$ & $\% \Lambda^{\circ}$ & 1 & $r$ & 17 & - Y \\
\hline$\% 10$ & $\% 10$ & $\%$ v & $r$ & $r$ & $1 \varepsilon$ & $\%$ & $\%$ & $\% \wedge 0$ & 1 & $r$ & iv & $-\Lambda$ \\
\hline$\%$ & $\%$ & $\%$ • & r & $r$ & 17 & $\%$ & $\%$ & $\% \wedge$. & $r$ & $r$ & 17 & -9 \\
\hline$\%$ & $\% 10$ & $\%{ }^{\wedge}$. & 1 & $r$ & 17 & $\%$ & $\% 10$ & $\%$ vo & $r$ & $r$ & 10 & .1. \\
\hline
\end{tabular}


مجلة بحوث التريية النوعية - عدد rr - أكتوير |l م - الجزء الأول بـ

جدول يوضـح تكرارات ونسب إجابات المحكمين لجميع بنود التصميمات المقترحة

\begin{tabular}{|c|c|c|c|c|c|c|c|c|c|c|c|c|}
\hline \multicolumn{6}{|c|}{ التصيم رقم r| } & \multicolumn{6}{|c|}{ التصميه رقم 11 } & \multirow{3}{*}{ P } \\
\hline \multicolumn{3}{|c|}{ النسبة./ } & \multicolumn{3}{|c|}{ العدد } & \multicolumn{3}{|c|}{ النسبة/\% } & \multicolumn{3}{|c|}{ العدد } & \\
\hline غير ملائم & إلي حدما & ملائم & غير ملائم & إلي حدما & ملائم & غير ملائم & إلي حدما & ملائم & غير هلائم & | إلي حد ما & ملائم & \\
\hline$\%$ & $\%$ & $\% \wedge$. & $r$ & $r$ & 17 & $\%$ & $\%$ & $\% .70$ & 1 & 1 & ir & -1 \\
\hline$\%$ & $\%$.ro & $\% 10$ & $r$ & 0 & ir & $\%$ & $\%$ & $\%$. & . & $\varepsilon$ & 17 & -r \\
\hline$\%$ & $\%$ & $\% .10$ & 1 & $r$ & iv & $\%$ & $\%$ & $\%$. & $r$ & $\varepsilon$ & IE & r \\
\hline$\%$ & $\%$ & $\%$ & $r$ & 9 & ir & $\% 10$ & $\%$ & $\%$ vo & $r$ & $r$ & 10 & $\varepsilon$ \\
\hline$\%$ & $\%$ & $\% v$. & $r$ & $\varepsilon$ & is & $\%$ & $\% 10$ & $\%$ vo & $r$ & $r$ & 10 & ـ \\
\hline$\%$ & $\%$.ro & $\% 00$ & $\varepsilon$ & 0 & 11 & $\%$ & $\%$ & $\%$ & $r$ & 1 & ir & -7 \\
\hline$\%$ & $\%$ & $\% .70$ & 1 & 7 & ir & $\% 10$ & $\%$ & $\%$ & $r$ & v & 1. & $-y$ \\
\hline$\%$ & $\%$ & $\%$. 0 & 1 & $\varepsilon$ & 10 & $\%$ & $\%$ & $\%$. 10 & 1 & $r$ & iv & $-\Lambda$ \\
\hline$\%$ & $\%$ & $\%$. & r & $r$ & 17 & $\%$ & $\%$.ro & $\% 10$ & $r$ & 0 & ir & -9 \\
\hline$\% 10$ & $\%$ ro & $\%$ & $r$ & 0 & ir & $\% 10$ & $\%$ & $\% 00$ & $r$ & 7 & 11 & -1. \\
\hline
\end{tabular}

جدول يوضح تكرارات ونسب إجابات المحكمين لجميع بنود التصميمات المقترحة

\begin{tabular}{|c|c|c|c|c|c|c|c|c|c|c|c|c|}
\hline \multicolumn{6}{|c|}{ التصميم رقم \&1 } & \multicolumn{6}{|c|}{ التصميم رقم r| } & \multirow{3}{*}{ A } \\
\hline \multicolumn{3}{|c|}{ النسبة/ } & \multicolumn{3}{|c|}{ العدد } & \multicolumn{3}{|c|}{ النسبة/ } & \multicolumn{3}{|c|}{ العدد } & \\
\hline ملائم & إلي حد & ملائم & غيائم & إلي حد & ملائم & غلائم & إلي حد & ملائم & غلائم & إلي حد & ملائم & \\
\hline$\% 10$ & $\%$ ro & $\%$ & $r$ & 0 & ir & $\%$ & $\% 10$ & $\%$ vo & r & $r$ & 10 & -1 \\
\hline$\%$ & $\%$ & $\% .70$ & 1 & 7 & ir & $\%$ & $\%$ r. & $\%$ vo & 1 & $\varepsilon$ & 10 & $-r$ \\
\hline$\% 10$ & $\%$ & $\%$ vo & $r$ & r & 10 & $\%$ & $\%$ & $\%$. 10 & 1 & r & iv & -r \\
\hline$\% 10$ & $\% 10$ & $\% \mathrm{v}$. & $r$ & $r$ & is & $\%$ & $\%$ & $\%$. & . & 1 & $1 \varepsilon$ & 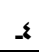 \\
\hline$\%$ & $\%$ & $\% 00$ & r & v & 11 & $\%$ & $\% 10$ & $\%$. & 1 & $r$ & 17 & هـ \\
\hline$\% 10$ & $\%$.ro & $\%$ & $r$ & 0 & ir & $\% 10$ & $\%$ & $\%$ vo & $r$ & $r$ & 10 & -7 \\
\hline$\% 10$ & $\%$ & $\% .70$ & $r$ & $\varepsilon$ & ir & $\% 10$ & $\% 10$ & $\%$. & $r$ & $r$ & $1 \varepsilon$ & $-r$ \\
\hline$\%$ & $\%$ & $\%$ & $\varepsilon$ & 1 & 1. & $\%$ & $\%$ & $\% 10$ & 1 & 7 & ir & $-\Lambda$ \\
\hline$\%$ & $\% r$ & $\% 00$ & 0 & $\varepsilon$ & 11 & $\%$ & $\%$ & $\%$ vo & 1 & $\varepsilon$ & 10 & 9 \\
\hline$\%$ & $\%$ ro & $\%$. & 1 & 0 & $1 \varepsilon$ & $\%$ & $\%$ & $\%$. & r & r & 17 & -1. \\
\hline
\end{tabular}




\begin{tabular}{|c|c|c|c|c|c|c|}
\hline \multirow{2}{*}{\multicolumn{6}{|c|}{ المحكمـين لجميـع بنود التصميمـات المقترحة }} & \\
\hline & & & & & & \multirow{3}{*}{ ค } \\
\hline \multicolumn{3}{|c|}{ النسبة/\% } & \multicolumn{3}{|c|}{ العدد } & \\
\hline غير ملائم & إلي حلد ما & ملائم & غير ملائم & إلي حد ما & ملائم & \\
\hline$\%$ & $\% 10$ & $\%$ Yo & r & $r$ & 10 & -1 \\
\hline$\%$ & $\%$ r & $\%$ ro & 1 & $\xi$ & 10 & $-r$ \\
\hline$\%$ & $\% 1$. & $\%$. & $r$ & $r$ & 17 & r \\
\hline$\%$ & $\% 1$. & $\% .10$ & 1 & $r$ & iv & كـ \\
\hline$\%$ & $\%$ & $\%$. & $r$ & $\varepsilon$ & Is & ـ \\
\hline$\%$ & $\% 10$ & $\%$ ro & $r$ & $r$ & 10 & -7 \\
\hline$\%$ & $\%$ r. & $\%$ vo & 1 & $\varepsilon$ & 10 & $-v$ \\
\hline$\%$ & $\% 10$ & $\%$. & 1 & $r$ & 17 & $-A$ \\
\hline$\% 10$ & $\% 10$ & $\% v$. & $r$ & $r$ & $1 \varepsilon$ & -9 \\
\hline$\% 1$. & $\%$ & $\%$ & $r$ & 9 & ir & -1. \\
\hline
\end{tabular}

جلدول يوضتح معاملات الجودة والمتوسط الوزنى لجميع التصميمات المقترحة

\begin{tabular}{|c|c|c|c|c|c|c|c|c|}
\hline \multicolumn{8}{|c|}{ التصميمات } & \multirow[t]{2}{*}{-} \\
\hline$\wedge$ & $v$ & 7 & 0 & $\varepsilon$ & $r$ & $r$ & 1 & \\
\hline$\%$.A. & $\% 97, v$ & $\%$ \% , & $\% \vee v, \vee$ & $\%$ & $\%$. & $\%$ & $\%$. & -1 \\
\hline$\%$. & $\% a r, r$ & $\%$. & $\% \vee \vee, \vee$ & $\% 97, v$ & $\% \wedge \Upsilon, \vee$ & $\% 97, \vee$ & $\% r r, r$ & $-r$ \\
\hline$\%$.А & $\% 9$. & $\% r r, r$ & $\%$ Аr, $\boldsymbol{r}$ & $\%$ & $\% \vee ५, \vee$ & $\% 9$. & $\% \vee \neg, \vee$ & $-r$ \\
\hline$\%$ /AT, r & $\% 97, \vee$ & $\%$. & $\% \wedge \uparrow, \curlyvee$ & $\% q r, r$ & $\%$. & $\%$ \% & $\% \wedge \uparrow, \vee$ & $\varepsilon$ \\
\hline$\%$ & $\% q r, r$ & $\% v r, r$ & $\%$ & $\% 9$. & $\%$ Ar, r & $\%$ ^ฯ, & $\%$ Ar, r & ـ \\
\hline$\%$.A. & $\% 97, v$ & $\% \vee \vee, \vee$ & $\% \vee r, r$ & $\% 97, v$ & $\% r r, r$ & $\%$. & $\% r r, r$ & -7 \\
\hline$\%(r, r$ & $\% q r, r$ & $\%$. & $\% \vee v, \vee$ & $\% a r, r$ & $\% \vee \neg, \vee$ & $\% 9$. & $\% v$. & $-y$ \\
\hline$\% \vee ฯ, \vee$ & $\% 1 \cdots$ & $\%$ Ar, $\boldsymbol{r}$ & $\% \vee r, r$ & $\% \wedge \Upsilon, \vee$ & $\%$. & $\%$ \% r, r & $\% \vee ฯ, \vee$ & $-\Lambda$ \\
\hline$\%$ Ar, r & $\% a r, r$ & $\%$. & $\%$ \%ฯ, & $\% 97, V$ & $\%$ Ar,r & $\%$ ^ฯ, & $\% \Lambda^{\circ}$ & -9 \\
\hline$\%$ ^^, & $\% 9$. & $\%$ \% , $\vee$ & $\%$. & $\% q r, r$ & $\% v$. & $\% 9$. & $\%$ Ar, r & -1. \\
\hline$\%$ \% & $\%$ & $\% V r$ & 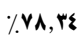 & $\% ৭ \xi, \vee$ & $\% \vee q$ & $\% \wedge \wedge$ & $\% \vee v, r$ & المتوسط العام \\
\hline$\wedge$ & $r$ & 10 & ir & 1 & 1. & $r$ & ir & الترتيب \\
\hline
\end{tabular}


مجلة بحوث التريية النوعية - عدد rr - أكتوير 1/ +r - الجزء الأول

جلدول يوضتح معاملات الجودة والمتوسط الوزنى لجميع التصميمات المقترحة

\begin{tabular}{|c|c|c|c|c|c|c|c|}
\hline \multicolumn{7}{|c|}{ التصميمات } & \multirow{2}{*}{+} \\
\hline 10 & 18 & ir & ir & 11 & 1. & 9 & \\
\hline$\%$ Ar, r & $\% V r, r$ & $\%$ ॥T, & $\% \wedge \uparrow, \vee$ & $\% \vee \vee, \vee$ & $\%$ /Ar, r & $\%$. & -1 \\
\hline$\%$ ॥r, r & $\% \vee v, \vee$ & $\%$ Ar, r & $\% \vee \neg, \vee$ & $\% \wedge \uparrow, \vee$ & $\% \wedge \uparrow, \curlyvee$ & $\% \wedge \uparrow, \vee$ & $-r$ \\
\hline$\% \wedge \uparrow, \vee$ & $\%$ Ar, r & $\% 9$. & $\% 9$. & $\%$. & $\% 9$. & $\% \vee v, \vee$ & -r \\
\hline$\% 9$. & $\%$. & $\%$. & $\% v r, r$ & $\%$ ॥r, $\boldsymbol{r}$ & $\%$ AT, & $\%$. & $\varepsilon$ \\
\hline$\%$. & $\%$. & $\% \wedge \uparrow, \vee$ & $\%$. & $\%$ ॥r, & $\% \wedge \uparrow, \vee$ & $\%$. & - \\
\hline$\%$ \% r, r & $\% \vee r, r$ & $\%$ ॥r, r & $\%$. & $\% v r, r$ & $\% 9$. & $\%$ & -7 \\
\hline$\%$ & $\%$ v , $\vee$ & $\%$. & $\% \vee \vee, \vee$ & $\%$ १५, & $\%$.AT, r & $\% \wedge \uparrow, \vee$ & $-Y$ \\
\hline$\% \wedge \uparrow, \vee$ & $\%$ \%ฯ, & $\% \vee \neg, \vee$ & $\%$ Ar, $\boldsymbol{r}$ & $\% 9$. & $\%$. & $\% 9$. & $-\Lambda$ \\
\hline$\%$. & $\%$. & $\%$ AT, r & $\% \wedge \uparrow, \vee$ & $\% \vee \vee, \vee$ & $\% \wedge \uparrow, \curlyvee$ & $\% \wedge \uparrow, \vee$ & -9 \\
\hline$\% \mathrm{Vr}, r$ & $\%$. & $\% \wedge \uparrow, \vee$ & $\% v r, r$ & $\%$. & 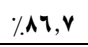 & $\%$ /AT, r & -1. \\
\hline$\%$ \%, 99 & $\%$. & \% & $\% \vee ৭, 7 \vee$ & 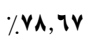 & $\% \wedge 0,7 \mathrm{~V}$ & $\%$ & المتوسط العام \\
\hline$v$ & $1 \varepsilon$ & 0 & 9 & 11 & $\xi$ & 9 & الترتيب \\
\hline
\end{tabular}

التصميم الأول :

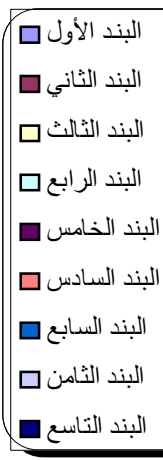

التصميم الاول

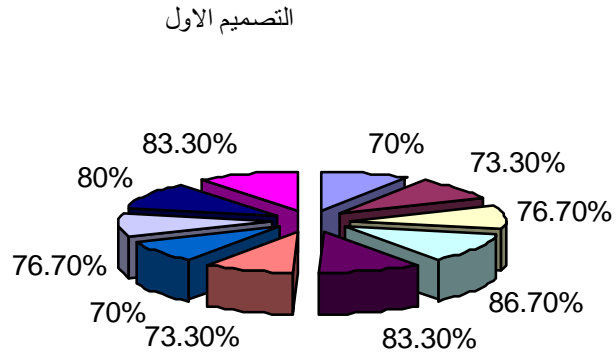

شكل يوضـح معاملات الجودة لجميع بنود تقييم التصميهم الأول

من الشكل السـابق نستخلص ما يلي :

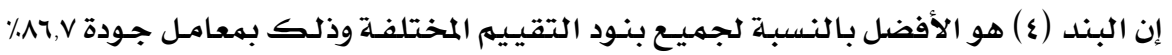

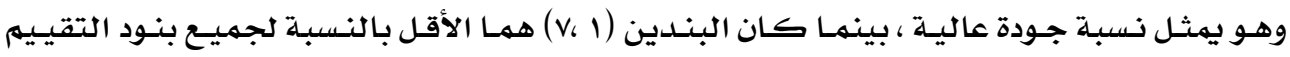

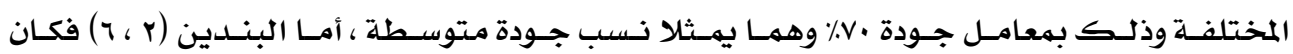




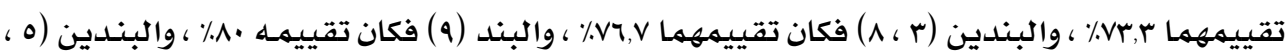
. التصميم الثاني : انقيدئ

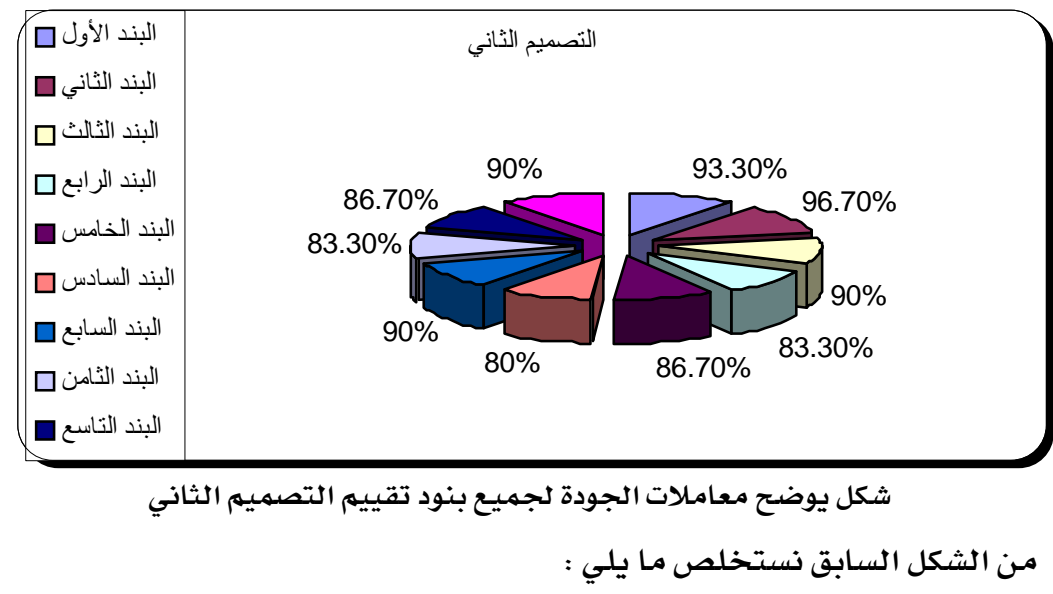

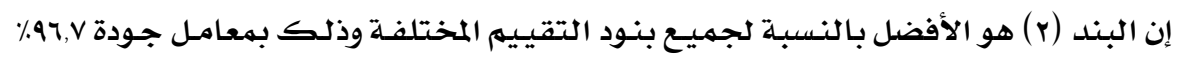

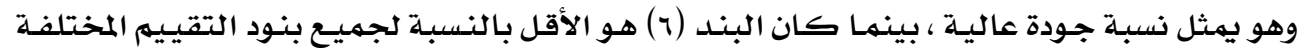

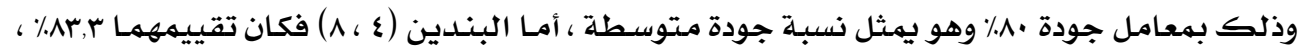

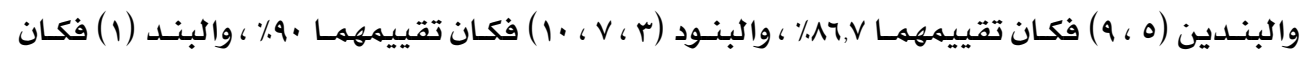

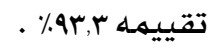
التصميه الثالث :

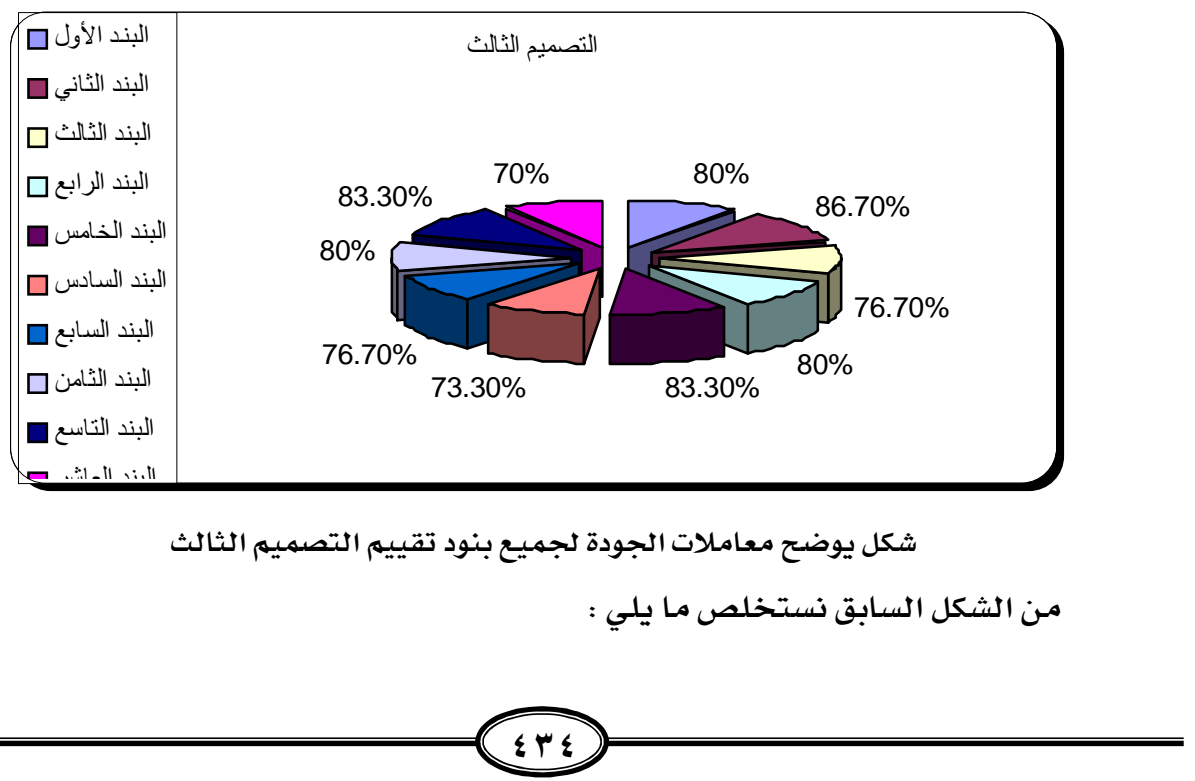




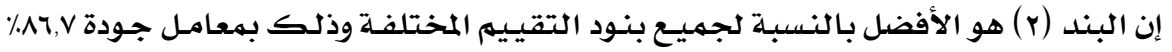

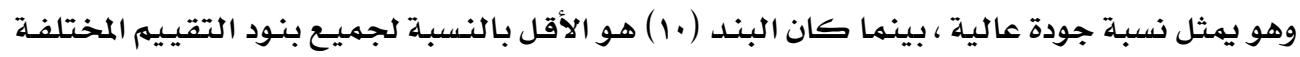

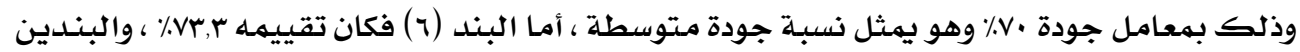

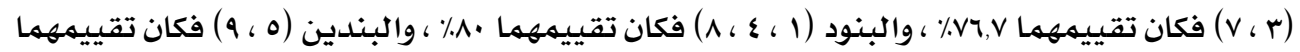
. •

التصميي الرابع :

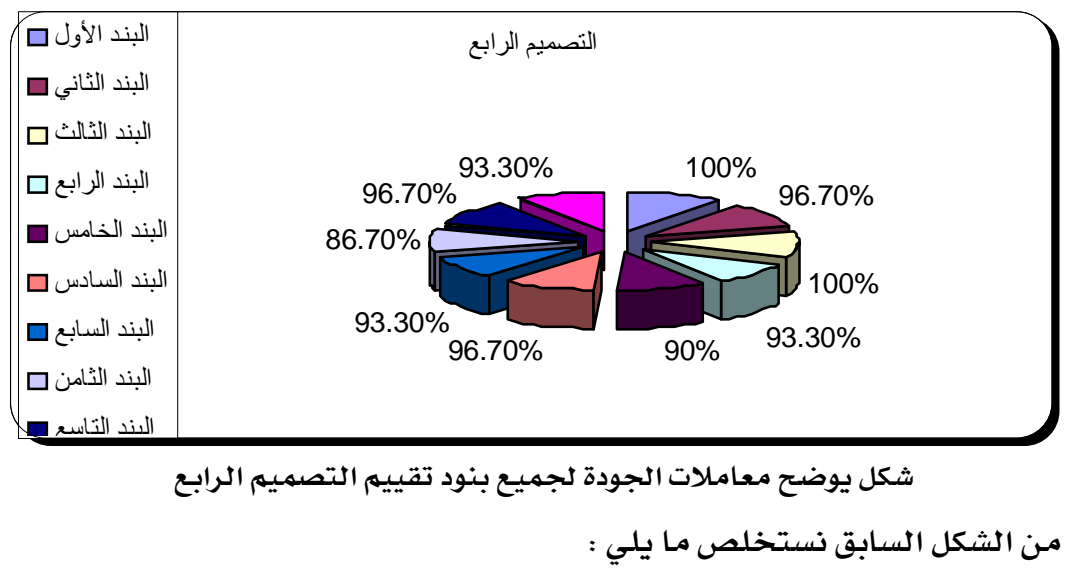

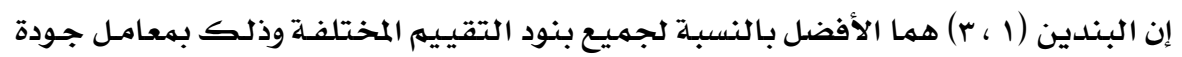

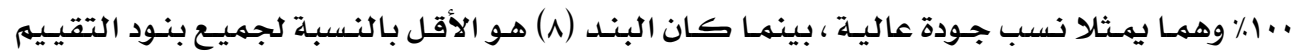

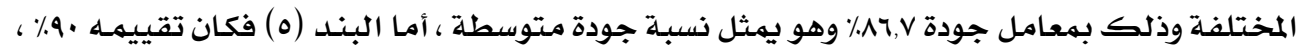

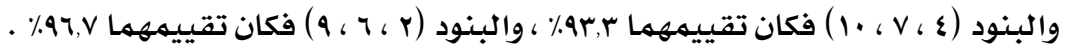
التصميم الخامس :

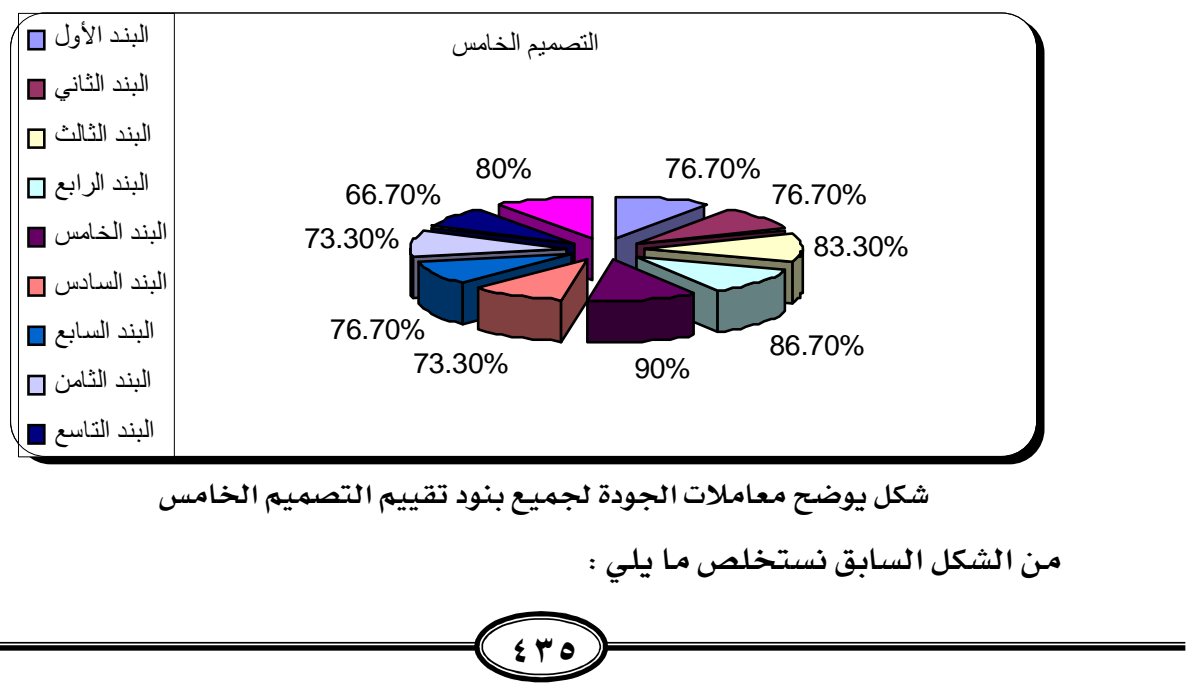




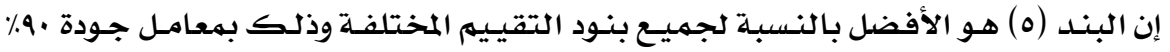

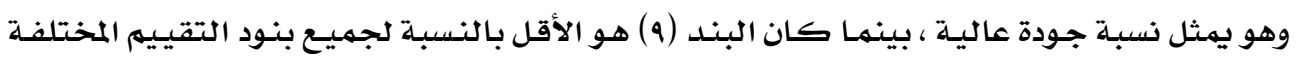

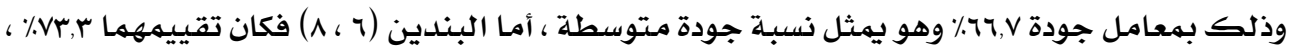

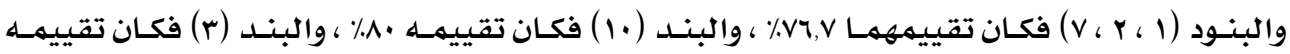

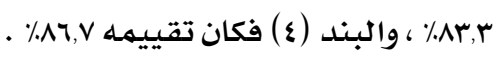
التصميه السادس :

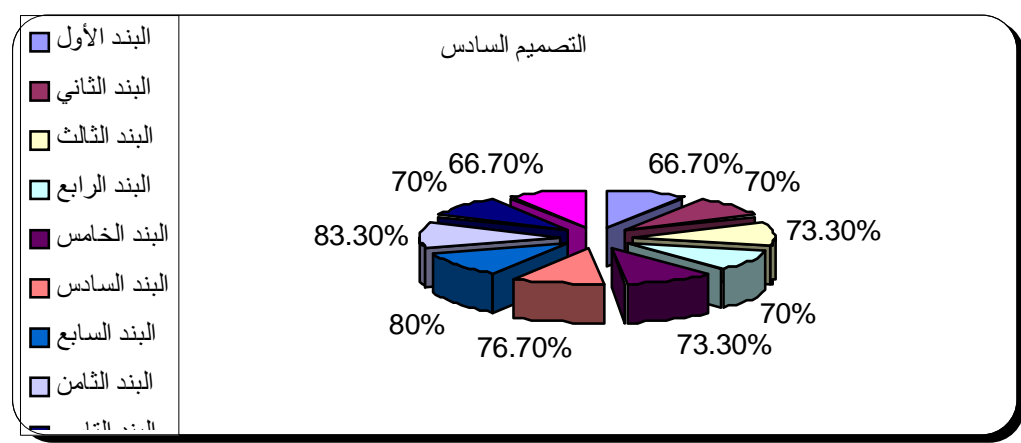

شكل يوضتح معاملات الجودة لجميع بنود تقييم التصميم السـادس

$$
\text { من الشكل السـابق نستخلص مـا يلي : }
$$

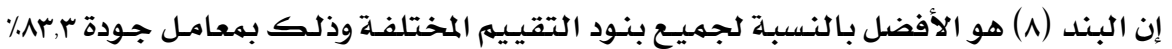
وهـو يمثل نسبـة جـودة عاليـة ، بينهـا كـان البنـدين (1 ، 1 ) همـا الأقل بـانـسبـة لجميـع بنـود التقيـيم

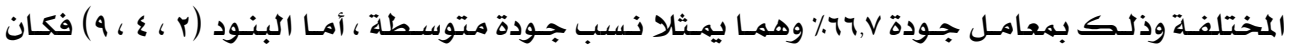

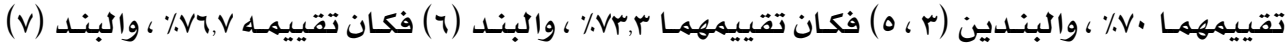

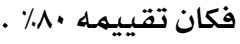

التصميه السابع : التصيه

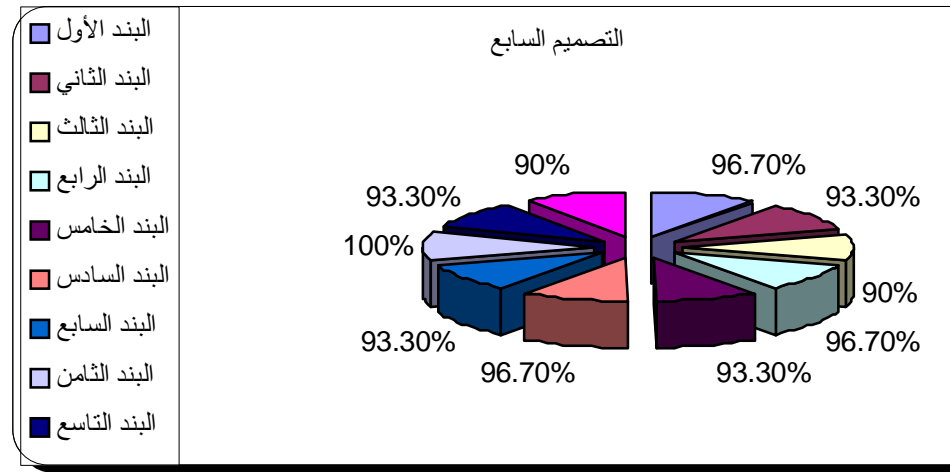

شكل يوضتح معاملات الجودة لجميع بنود تقييهم التصميهم السابع 


$$
\text { من الشكل السابق نستخلص ما يلي : }
$$

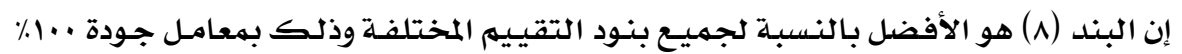

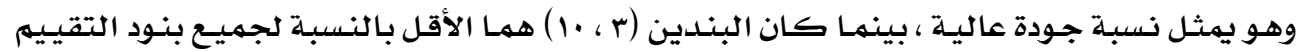

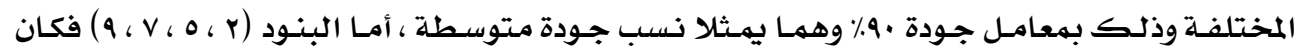

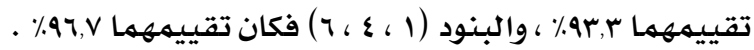
التصميم الثامن :

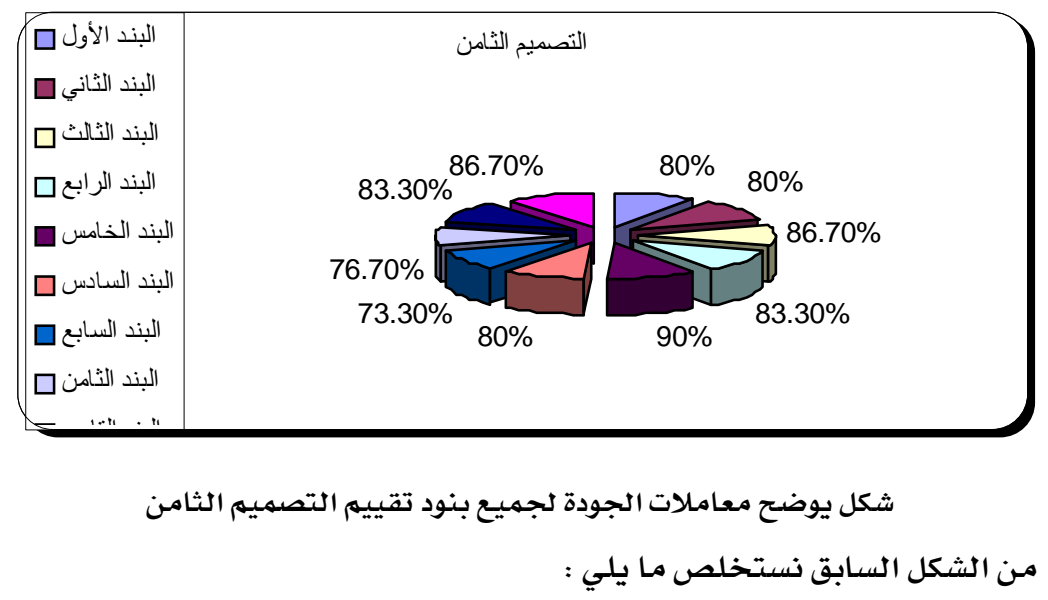

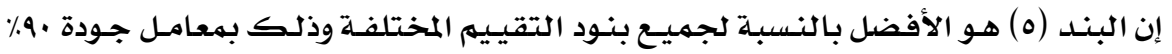

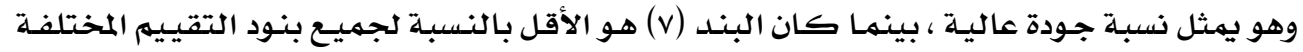

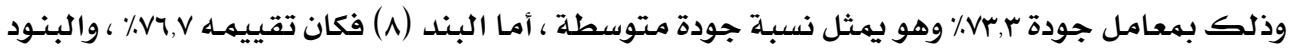

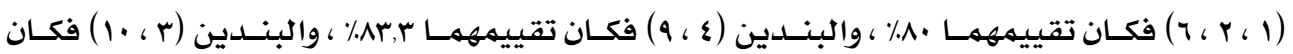
تقييمهما V التصميي التاسع :

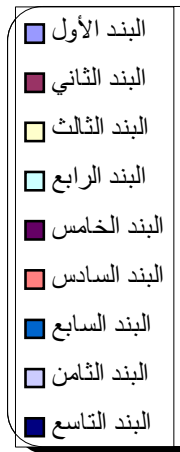

شكل يوضـح معاملات الجودة لجميـع بنود تقييهم التصميهم التاسـع 


$$
\text { من الشكل السابق نستخلص ما يلي : }
$$

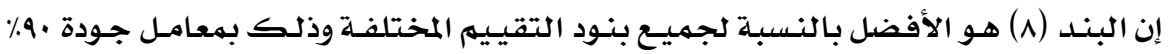

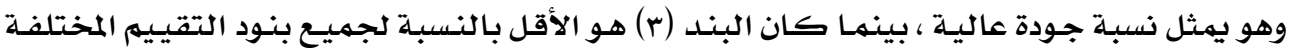

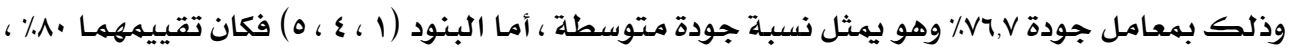

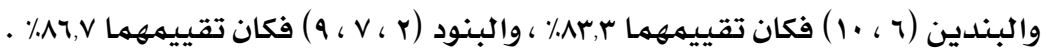

التصميم العاشر :

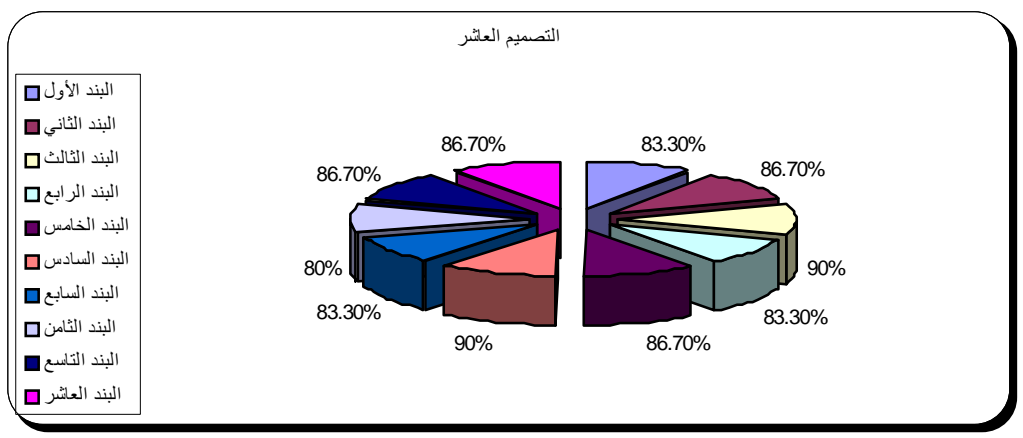

شكل يوضـح معاملات الجودة لجميع بنود تقييم التصميهم العاشر

من الشكل السـابق نستخلص مـا يلي :

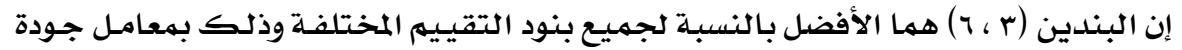

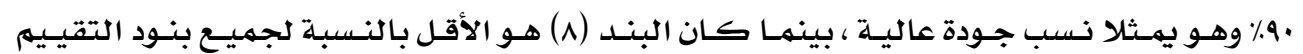

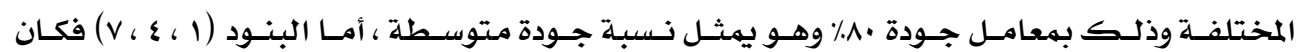

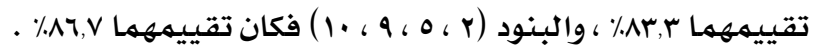

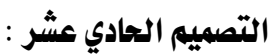

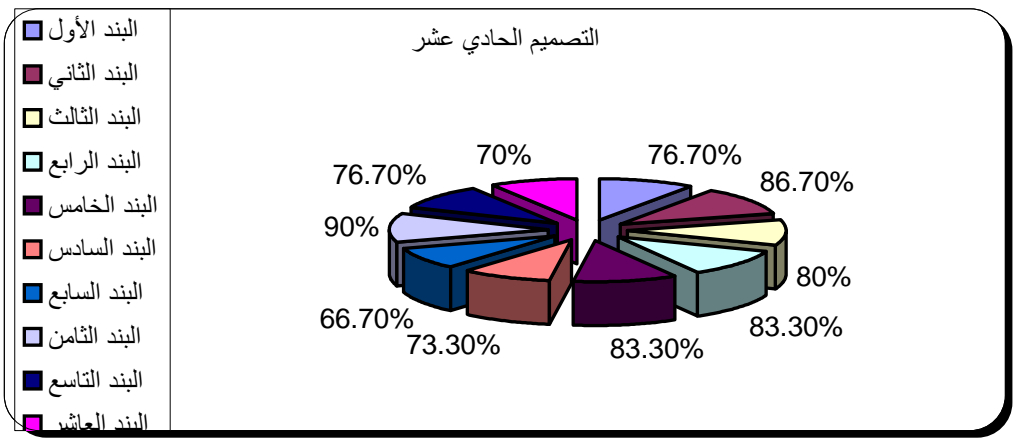

شكل يوضـح معاملات الجودة لجميع بنود تقييم التصميهم الحادي عشر من الشكل السابق نستخلص ما يلي : 


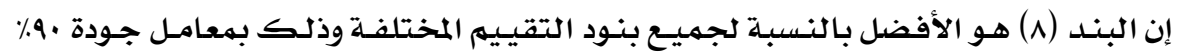

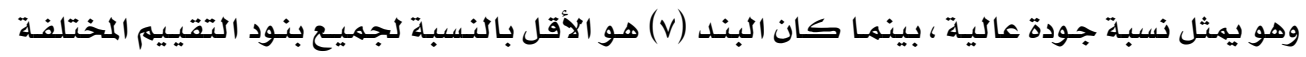

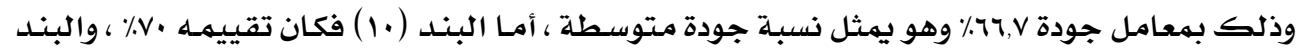

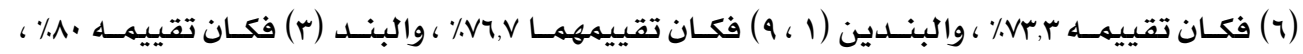

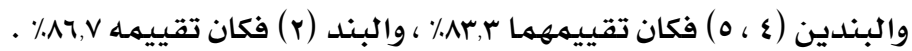
التصميي الثاني عشر :

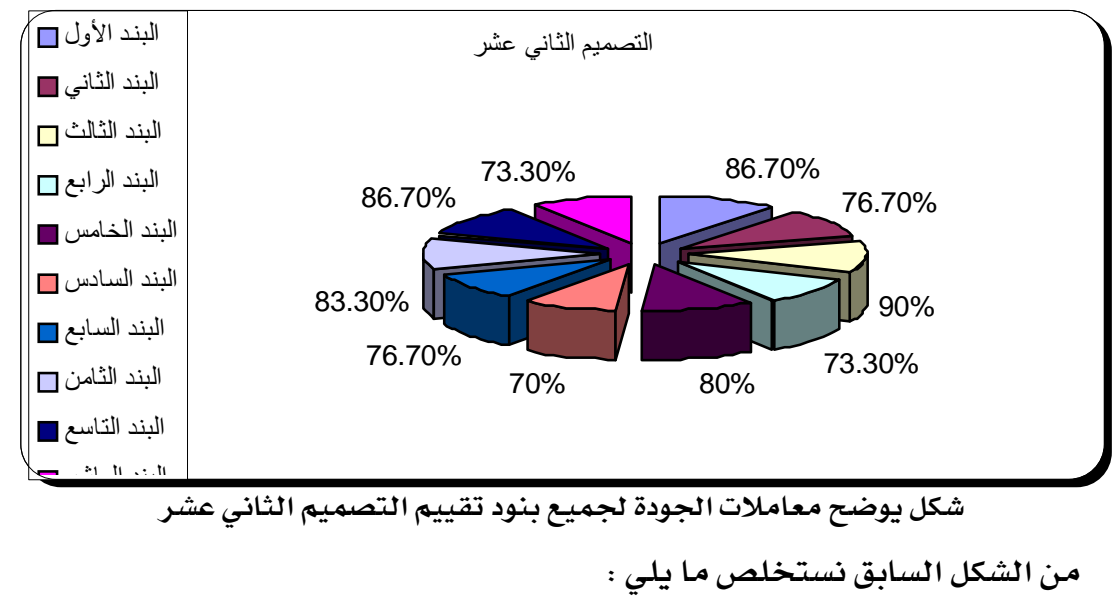

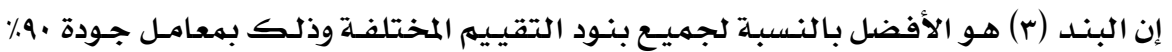

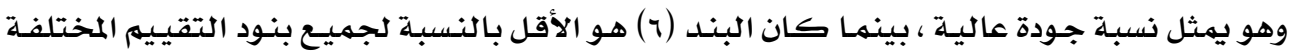

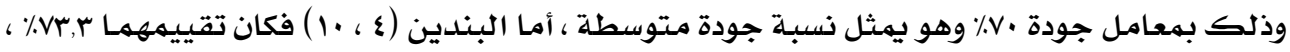

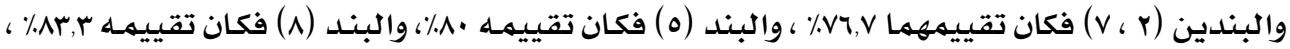

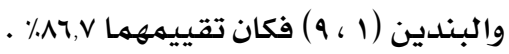
التصميي الثالث عشر :

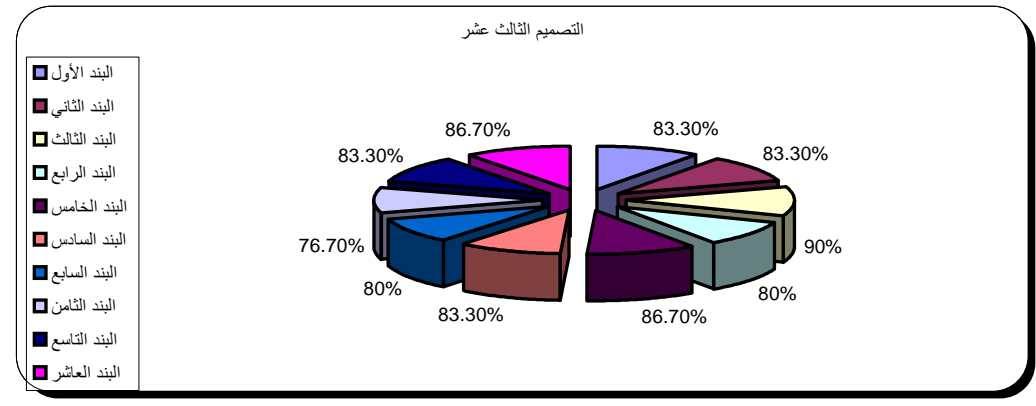

شكل يوضح معاملات الجودة لجميع بنود تقييم التصميم الثالث عشر من الشكل السابق نستخلص ما يلي : 


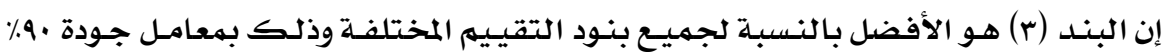

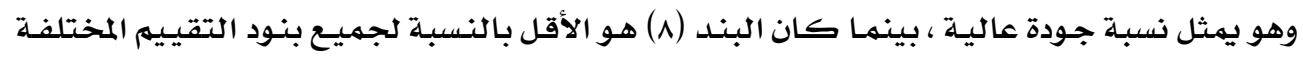

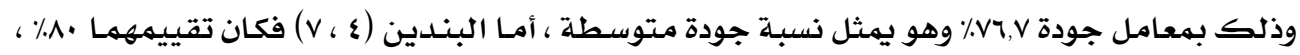

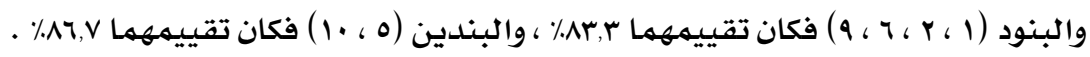
التصميي الرابع عشر :

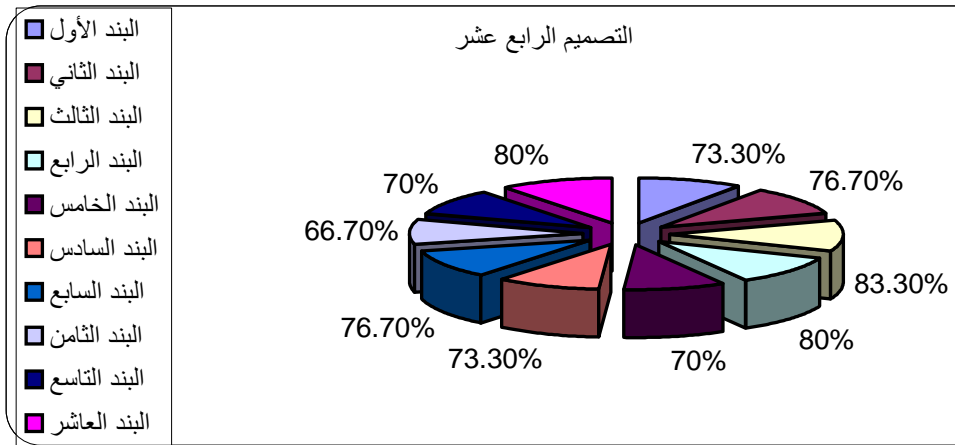

$$
\begin{aligned}
& \text { شكل يوضح معاملات الجودة لجميع بنود تقييم التصميم الرابع عشر } \\
& \text { من الشكل السابق نستخلص ما يلي : }
\end{aligned}
$$

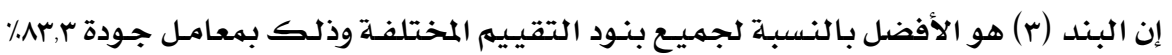

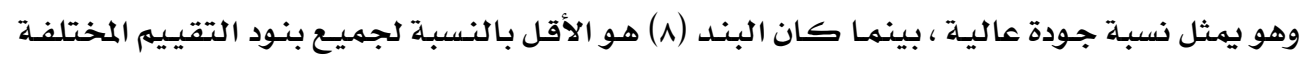

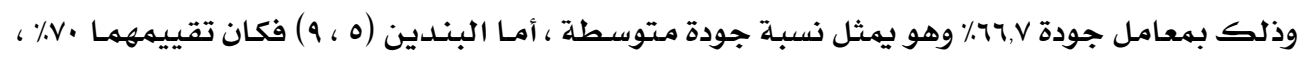

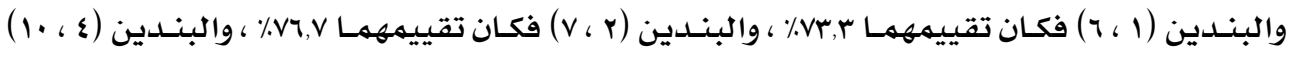

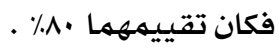
التصميم الخامس عشر :

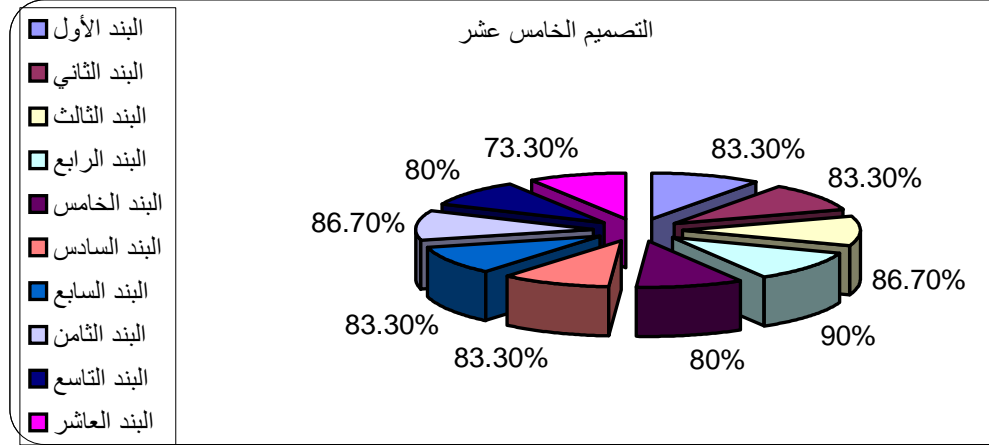

$$
\begin{aligned}
& \text { شكل يوضـح معاملات الجودة لجميع بنود تقييم التصميم الخامس عشر } \\
& \text { من الشكل السابق نستخلص ما يلي : }
\end{aligned}
$$




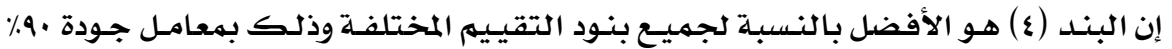

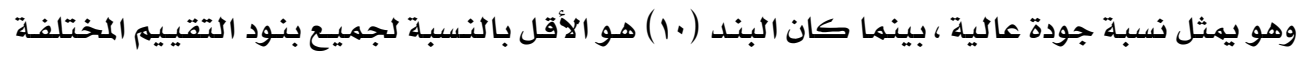

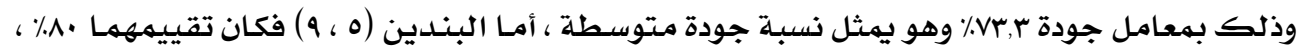

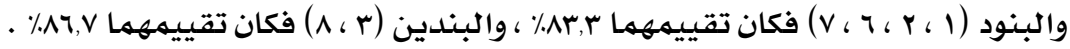

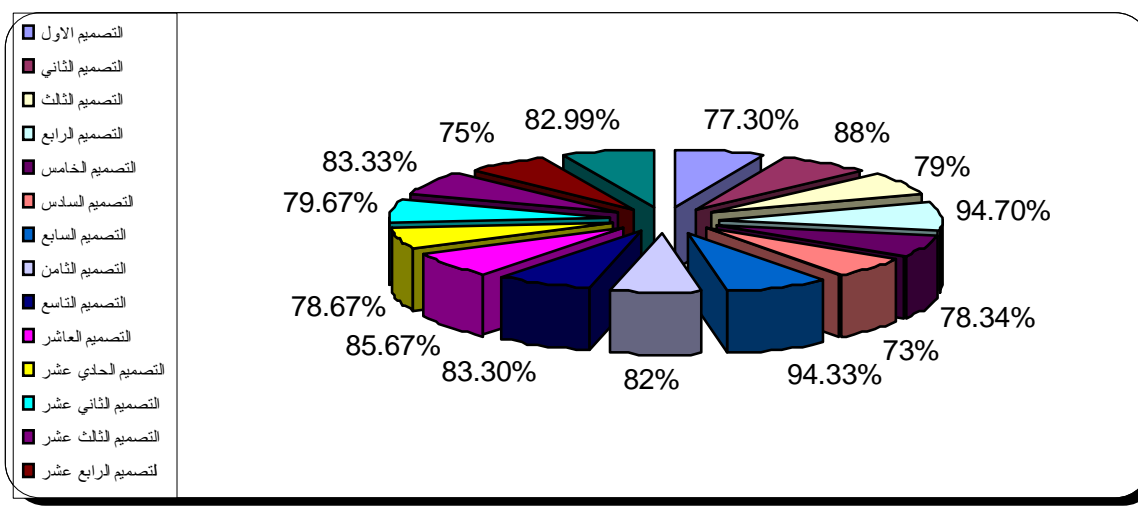

شكل يوضح التقييم العام لمعامل الجودة للتصميمات المقترحة من الشكل السابق نستخلص ما يلي :

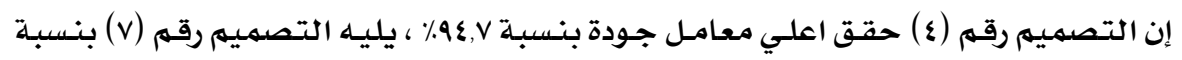

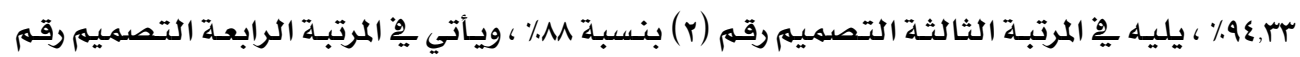

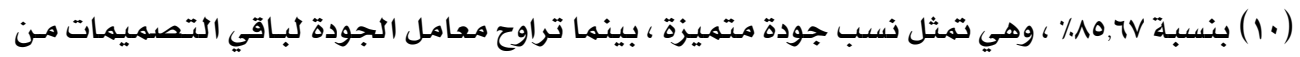

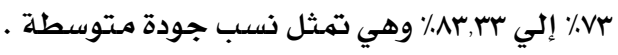
I. توصى الباحثة بضرورة دراسة القيه التشكيلية التى تزخر بها الطبيعة .

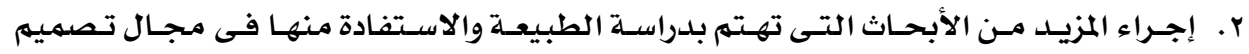
الأزياء. r. ضرورة الاتجاه لابتكار صياغات فنية جديدة تثرى مجال تصميم الأزياء .

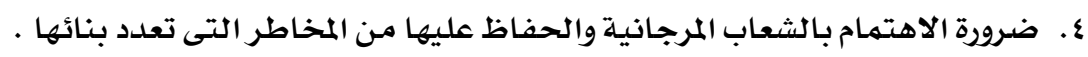


ا. أحمد حافظ رشدان - فتح البـاب عبد الحليه : "التصميهم فى الفن التشكيلى" ، عالم الكتب ، القـاهرة ،

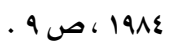

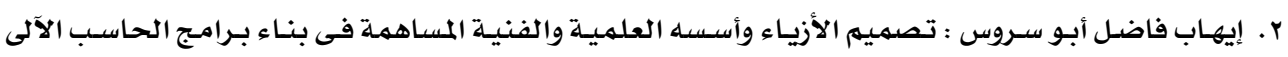

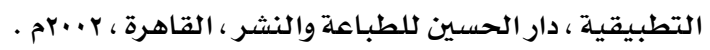

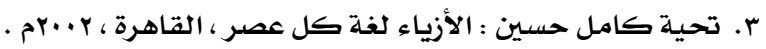

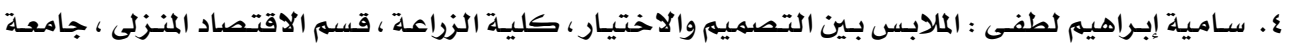

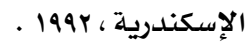

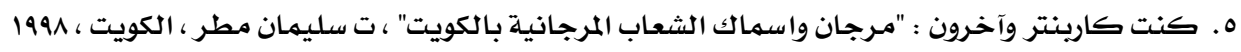

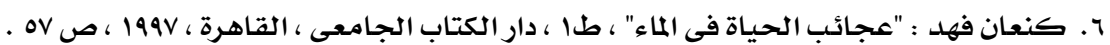

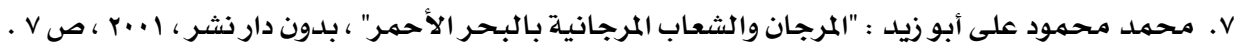

8. Guellge v.v "Design in Nature" Art Resources Publication, inc, N. Y., 1999, P. 29.

9. Johm, Patrick, Encyclopedia of fashion detalils, Irland, bt. Batspord htd, London, 1989.

10.http://www.prameg.com

11.http:/www.mahjoob.com 


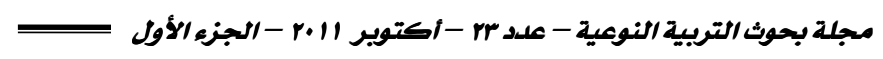 \\ هلمق همياس التقدير \\ بسم الله الرحمن الرحيم اليميم
}

\author{
جامعة المنصورة \\ كلية التربية النوعية \\ قسم الاقتصاد المنزلي
}

مقياس التقدير

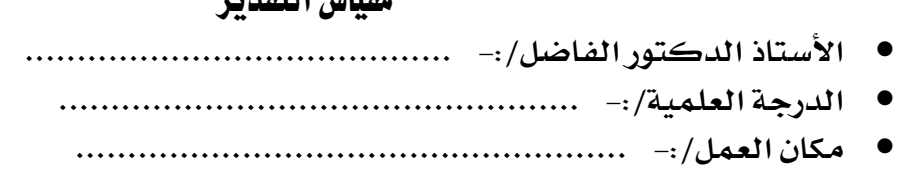

تحية طيبـة وبعد،،،؛

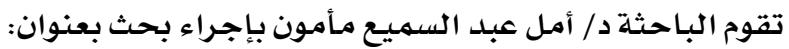

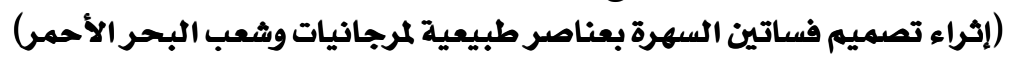

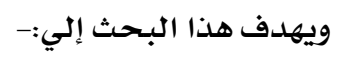

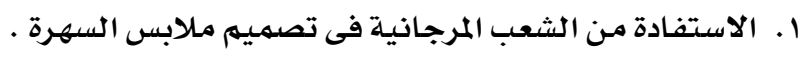

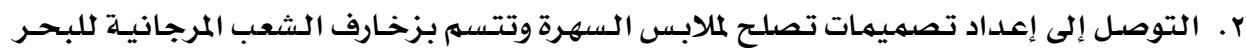

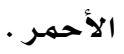

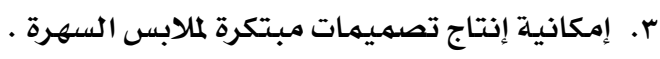

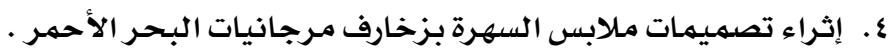

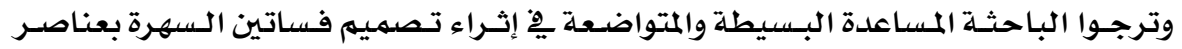

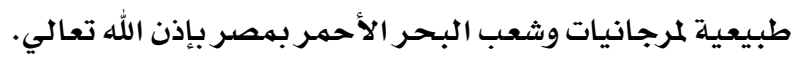

\begin{tabular}{|c|c|c|c|c|}
\hline غير موافق & موافق إلى حد ما & موافق & العبــــــــات & P \\
\hline & & & إمكانية الاستفادة من الكائنات البحرية في تجميل ملابس السهرة . & 1 \\
\hline & & & تتقبل المرأة ارتداء ملابس سهرة مطرزة بزخارف مستوحاة من الشعب المرجانية & $r$ \\
\hline & & & تتلائم ملابس السهرة مع الاستخدام والفرض منها. & $r$ \\
\hline & & & يتناسب التصميم مع متطلبات الموضة . & $\mathfrak{\varepsilon}$ \\
\hline & & & إمكانية استخدام الزخارف المرجانية فى تجميل ملابس السهرة بأكثر من طريقة . & 0 \\
\hline & & & تتميز التصميمات المقترحة بالناحية الفنية المبتكرة . & 9 \\
\hline & & & حلدوث تناسب بين الألوان الطبيعية للشعب المرجانية وشكل التصميم النهائي . & r \\
\hline & & & يتحقق الاتزان فى التصميم بعد إخافة الوحدات التصميمية . & $\wedge$ \\
\hline & & & يتحقق الإيقاع فى التصميمات المنفذة . & 9 \\
\hline & & & يتناسب أسلوب التطريز اليدوى لشعب المرجانية وملابس السهرة . & 1. \\
\hline
\end{tabular}

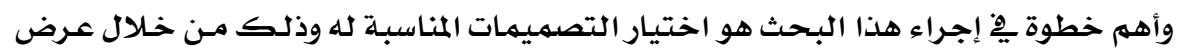

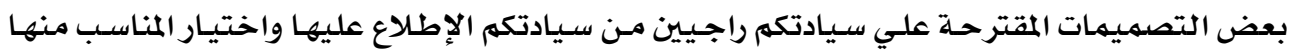

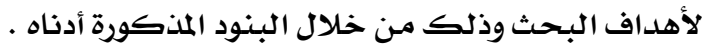

التصميم الأول 